\title{
Diurnal variation and size dependence of the hygroscopicity of organic aerosol at a forest site in Wakayama, Japan: their relationship to $\mathrm{CCN}$ concentrations
}

\author{
Yange Deng $^{1,2}$, Hikari Yai ${ }^{1}$, Hiroaki Fujinari ${ }^{1}$, Kaori Kawana ${ }^{3, a}$, Tomoki Nakayama ${ }^{2, b}$, and Michihiro Mochida ${ }^{1,2}$ \\ ${ }^{1}$ Graduate School of Environmental Studies, Nagoya University, Nagoya, Japan \\ ${ }^{2}$ Institute for Space-Earth Environmental Research, Nagoya University, Nagoya, Japan \\ ${ }^{3}$ Institute of Low Temperature Science, Hokkaido University, Hokkaido, Japan \\ anow at: Research and Development Center for Global Change, Japan Agency for Marine-Earth Science \\ and Technology, Yokohama, Japan \\ ${ }^{b}$ now at: Graduate School of Fisheries and Environmental Sciences, Nagasaki University, Nagasaki, Japan
}

Correspondence: Michihiro Mochida (mochida@isee.nagoya-u.ac.jp)

Received: 29 August 2018 - Discussion started: 16 October 2018

Revised: 19 March 2019 - Accepted: 25 March 2019 - Published: 6 May 2019

\begin{abstract}
Formation of biogenic secondary organic aerosol (BSOA) and its subsequent evolution can modify the hygroscopicity of the organic aerosol component (OA) in the forest atmosphere, and affect the concentrations of cloud condensation nuclei $(\mathrm{CCN})$ there. In this study, size-resolved aerosol hygroscopic growth at $85 \%$ relative humidity and size-resolved aerosol composition were measured using a hygroscopic tandem differential mobility analyzer and an aerosol mass spectrometer, respectively, at a forest site in Wakayama, Japan, in August and September 2015. The hygroscopicity parameter of OA $\left(\kappa_{\mathrm{org}}\right)$ presented daily minima in the afternoon hours, and it also showed an increase with the increase in particle dry diameter. The magnitudes of the diurnal variations in $\kappa_{\mathrm{org}}$ for particles with dry diameters of 100 and $300 \mathrm{~nm}$ were on average 0.091 and 0.096 , respectively, and the difference in $\kappa_{\text {org }}$ between particles with dry diameters of 100 and $300 \mathrm{~nm}$ was on average 0.056 . The relative contributions of the estimated fresh BSOA and regional OA to total OA could explain $40 \%$ of the observed diurnal variations and size dependence of $\kappa_{\text {org }}$. The hygroscopicity parameter of fresh BSOA was estimated to range from 0.089 to 0.12 for particles with dry diameters from 100 to $300 \mathrm{~nm}$. Compared with the use of time- and size-resolved $\kappa_{\text {org }}$, the use of time- and size-averaged $\kappa_{\text {org }}$ leads to under- and overestimation of the fractional contribution of $\mathrm{OA}$ to $\mathrm{CCN}$ number concentrations in the range from $-5.0 \%$ to $26 \%$. This indicates that the diurnal variations and size dependence of
\end{abstract}

$\kappa_{\text {org }}$ strongly affect the overall contribution of OA to CCN concentrations. The fractional contribution of fresh BSOA to $\mathrm{CCN}$ number concentrations could reach 0.28 during the period of intensive BSOA formation. The aging of the fresh BSOA, if it occurs, increases the estimated contribution of BSOA to CCN number concentrations by $52 \%-84 \%$.

\section{Introduction}

The hygroscopicity (ability to absorb water) of organic aerosol (OA) components is governed by their chemical composition, and has two important roles in the atmosphere. It influences light scattering by aerosols (Titos et al., 2016) and affects the ability of aerosols to work as cloud condensation nuclei (CCN; McFiggans et al., 2006). The hygroscopicity of OA may also influence the aqueous chemistry in aerosols and cloud droplets, which provide a potentially important pathway for the formation of secondary organic aerosols (SOA; McNeill, 2015). Nevertheless, the hygroscopicity of OA is not well characterized in terms of its temporal and spatial variations, size dependence, and its relationship with the chemical composition of OA, given that OA is a complex mixture of a number of compounds.

Studies on the hygroscopicity parameter $\kappa$ of OA $\left(\kappa_{\mathrm{org}}\right.$; Petters and Kreidenweis, 2007) in different locations have 
presented different characteristics of temporal variation and size dependence. Based on a year-long observation under supersaturated water vapor conditions (SUPS) at a downwind site of Manaus in central Amazonia, Thalman et al. (2017) reported that $\kappa_{\text {org }}$ presented the lowest value of $\sim 0.1$ in September and the highest value of $\sim 0.15$ in December, and that the ranges of the diurnal variations in $\kappa_{\text {org }}$ were 0.10 to 0.16 (night to day) and 0.08 to 0.14 (night to day) under the influence of local biomass-burning air masses during the dry season and urban-pollution air masses during the wet season, respectively. Bougiatioti et al. (2016) reported diurnal variation in $\kappa_{\text {org }}$ in the range $0.09-0.18$ (day to night) under SUPS for particles influenced by biomass burning in the eastern Mediterranean. Deng et al. (2018) reported diurnal variation ranges of $\kappa_{\text {org }}$ of 0.09 to 0.30 (day to night) and 0.16 to 0.24 (day to night) on days with and without evident new particle formation (NPF), respectively, under a SUPS $(0.23 \%$ water vapor supersaturation (SS) condition) in a forest in Wakayama, Japan. Different from the above studies, at a rural site in the southeastern United States, a small diurnal variation in $\kappa_{\text {org }}(\sim 0.13$ to $\sim 0.17$, night to day) under SUPS was observed (Cerully et al., 2015). With respect to the size dependence of $\kappa_{\text {org }}$, airborne studies over United States, Canada, Pacific Ocean, and the Gulf of Mexico for a variety of air mass types presented a decrease in $\kappa_{\text {org }}$ (from 0.13 to 0.06 ) with an increase in the particle modal diameter (from 130 to $\sim 210 \mathrm{~nm}$ ) under subsaturated water vapor conditions (SUBS) (Shingler et al., 2016). By contrast, ground-based observations in the city of Nagoya in Japan under SUBS presented relatively low $\kappa_{\text {org }}$ in small particles $(0.12-0.15 ; 60$ and $100 \mathrm{~nm})$ and high $\kappa_{\text {org }}$ in large particles (0.17-0.22; 200 and $359 \mathrm{~nm}$ ) (Kawana et al., 2016). For aerosols found in forest areas, Deng et al. (2018) reported a difference of 0.03 in mean $\kappa_{\text {org }}$ between sub- $100 \mathrm{~nm}$ particles $\left(\kappa_{\text {org }}\right.$ was 0.19$)$ and $\sim 150 \mathrm{~nm}$ particles $\left(\kappa_{\text {org }}\right.$ was 0.22$)$, whereas Thalman et al. (2017) did not identify any size dependence of $\kappa_{\text {org }}$ for $94-171 \mathrm{~nm}$ particles. The hygroscopicity of laboratory-generated model SOA was also reported to be size-dependent. Frosch et al. (2011) reported that the $\kappa$ of $\alpha$-pinene SOA at SUPS at $100 \mathrm{~nm}(\sim 0.12)$ was $\sim 0.06$ higher than at $200 \mathrm{~nm}$. Zhao et al. (2015) reported that the $\kappa$ values of model SOA at SUPS produced by different precursors at 50,100, and $200 \mathrm{~nm}$ were $\sim 0.17, \sim 0.11$, and $\sim 0.07$, respectively. Tritscher et al. (2011) also found that small $(50 \mathrm{~nm}) \alpha$-pinene SOA particles had a higher $\kappa$ than large ones $(150 \mathrm{~nm})$ at SUBS, although the difference was small (0.03). Frosch et al. (2013) reported that the $\kappa$ of $\beta$ caryophyllene SOA decreased with the increase in SS, which can be interpreted as the increase in $\kappa$ with the increase in particle diameter, and that the maximum of the difference was about 0.1 .

The variations in $\kappa_{\text {org }}$ observed in the aforementioned studies may have great influence on the prediction of $\mathrm{CCN}$. Based on global climate modeling simulations, Liu and Wang (2010) reported that CCN concentration would change within $40 \%$ by changing the $\kappa$ of SOA by $\pm 50 \%$ (from 0.14 to 0.07 or 0.21 ). Rastak et al. (2017) reported that the difference in the aerosol radiative effects between $\kappa_{\text {org }}$ of 0.05 and 0.15 was $-1.02 \mathrm{~W} \mathrm{~m}^{-2}$, the order of which is the same as that of the overall climate forcing effect of anthropogenic aerosol during the industrial period. Based on $\mathrm{CCN}$ closure studies, Wang et al. (2008) reported that, for above-cloud aerosols with high volume fractions of OA, while the CCN number concentration closure could be achieved using $\kappa_{\text {org }}$ of 0.12 , the use of $\kappa_{\text {org }}$ of 0.25 led to overestimation of the CCN number concentration by $50 \%$. Mei et al. (2013b) reported that the increase in $\kappa_{\text {org }}$ from 0.08 to 0.13 led to a $30 \%$ increase in the calculated CCN number concentration and that the increase from 0.03 to 0.18 doubled the concentration. It is therefore important to study the temporal variation and size dependence of $\kappa_{\text {org }}$ in more locations where OA dominates the aerosol chemical composition, to characterize the $\kappa_{\text {org }}$ values and to represent $\kappa_{\text {org }}$ appropriately in model predictions of $\mathrm{CCN}$ number concentrations.

The temporal variation and size dependence of $\kappa_{\text {org }}$ of ambient aerosol is reported to relate to variations in the chemical composition of OA, which can result from the mixing of aerosols of different origins, formation of SOA, and aging processes (Cerully et al., 2015; Bougiatioti et al., 2016; Shingler et al., 2016; Thalman et al., 2017; Deng et al., 2018). The size-dependent chemical composition of model SOA has been explained by the size-dependent contributions of different organic vapors to particle growth (e.g., Winkler et al., 2012; Ehn et al., 2014; Zhao et al., 2015, 2016). The sizedependent $\kappa$ of model SOA has also been explained from the viewpoint of size-dependent chemical composition (Zhao et al., 2015; Frosch et al., 2013) and other factors: the dependence of water activity on particle size, the dependence of the surface tension on the solution concentration, and the evaporation of semivolatile SOA under high-SS conditions (Frosch et al., 2011, 2013; Zhao et al., 2015). In recent studies, the variation in $\kappa_{\text {org }}$ was explained by the variation in OA subcomponents derived from positive matrix factorization (PMF) analysis of OA mass spectra (Cerully et al., 2015; Bougiatioti et al., 2016). From these studies it is reported that the daily variation in $\kappa_{\text {org }}$ could be well explained by the daily variation in the contributions of the retrieved PMF factors to $\kappa_{\text {org }}$.

In the forest atmosphere, the oxidation of biogenic volatile organic compounds (BVOC) emitted by vegetation can produce substantial amounts of biogenic secondary organic aerosols (BSOA; Tunved et al., 2006; Pöschl et al., 2010; Han et al., 2014). BSOA is reported to contribute to the growth of newly formed particles in forests (e.g., Han et al., 2013; Yu et al., 2014; Zhou et al., 2015). BSOA may also condense on preexisting background particles or particles transported with inflowing air masses (e.g., Cerully et al., 2015; Thalman et al., 2017). Moreover, BSOA is subject to aging processes that include photochemical oxidation and aqueous-phase reactions that must depend on ambient meteorological condi- 
tions (e.g., Han et al., 2014; Thalman et al., 2017). Such processes could result in time- and size-dependent variation in the chemical composition of OA and thus time- and sizedependent $\kappa_{\text {org }}$ in the forest atmosphere. However, the characteristics of the temporal variations and size dependence of $\kappa_{\text {org }}$, and their relationships to the atmospheric processes of BSOA in forest environments, are not well understood.

We performed field observation at a forest site in Wakayama, Japan, in August and September 2015 and characterized the diurnal variations and size dependence of $\kappa_{\text {org }}$. The variations and dependence were interpreted based upon the size-resolved chemical composition of OA from the viewpoint of BSOA formation. Furthermore, the influence of these variations on the fractional contribution of $\mathrm{OA}$ and $\mathrm{BSOA}$ to the $\mathrm{CCN}$ concentration was assessed. Previous observational studies at the site indicated that BSOA formation was intensive and that aging occurred after formation (Han et al., 2014; Deng et al., 2018). It was also observed that $\kappa_{\text {org }}$ was time- and size-dependent and that the contribution of OA and BSOA to CCN number concentrations could be substantial (Deng et al., 2018). This work is an extension of previous studies on the hygroscopicity and CCN activity of aerosols, and the contributions of OA and BSOA to the CCN concentration, in the same forest (Kawana et al., 2017; Deng et al., 2018). It is intended to clarify the diurnal variation and size dependence of the hygroscopicity of OA and their influence on the contributions of OA and BSOA to CCN.

\section{Field observation}

The field observation was performed at Wakayama Forest Research Station, Kyoto University $\left(34.06^{\circ} \mathrm{N}, 135.52^{\circ} \mathrm{E}\right.$, about $500 \mathrm{~m}$ above sea level), located in the central part of the Kii Peninsula. The observation site is about $70 \mathrm{~km}$ south of Osaka (2.7 million inhabitants) and $60 \mathrm{~km}$ northwest of the North Pacific. Both coniferous trees (such as Cryptomeria japonica, Chamaecyparis obtuse, and Pinus densiflora) and broad-leaf trees (such as Quercus serrata and Quercus crispula) are distributed on the Kii Peninsula (Okumura, 2009). The study period was from 14:30 Japan Standard Time (JST) on 31 August to 06:00 JST on 22 September 2015 .

The hygroscopic growth at $85 \%$ relative humidity (RH), number-size distributions, and size-resolved chemical composition of ambient aerosols were measured using a hygroscopicity tandem differential mobility analyzer (HTDMA), a scanning mobility particle sizer (SMPS), and a highresolution time-of-flight aerosol mass spectrometer (AMS), respectively. Ambient air was aspirated from an inlet about $7.5 \mathrm{~m}$ above the ground. The air was transferred through a $\mathrm{PM}_{2.5}$ cyclone (URG) installed at the lower end of the $10.4 \mathrm{~m}$ stainless-steel inlet tubing (1/2 in. OD) and introduced to the instrument room at a flow rate of $16.7 \mathrm{~L} \mathrm{~min}^{-1}$. A manifold combined with an assistant pump (ULVAC, DA30S) was used to split the air flow, and the sample flow for the instrument system composed of the HTDMA, SMPS, and AMS was $0.9 \mathrm{~L} \mathrm{~min}^{-1}$. The sample flow upstream of the AMS was dried with two diffusion driers containing silica gel. The sample flow to the HTDMA and SMPS was dried with three diffusion driers, in series, two with silica gel and one with molecular sieves.

In the HTDMA, the dried aerosol $(\mathrm{RH}<1.8 \%)$ was passed through the first differential mobility analyzer (DMA1; 3081, TSI), where the aerosol was classified, and quasimonodisperse particles of 30,50,70,100, 200,300, and $360 \mathrm{~nm}$ in diameter $\left(d_{\mathrm{dry}}\right)$ were obtained. The setting for the classification was fixed for $5 \mathrm{~min}$ at each diameter. In each hour, the sequential diameter setting of DMA1 was 30, 50, $70,100,200,360,30,50,100,200,300$, and $360 \mathrm{~nm}$. During 05:50-05:54 and 17:50-17:54 JST, the setting of DMA1 was for system performance check. The classified aerosol was passed through a Nafion humidifier (MD-110-24S-4, Perma Pure) where it was humidified to $\sim 85 \%$ RH. The aerosol was then introduced to a second DMA (DMA2; 3081, TSI) coupled to a condensation particle counter (CPC, 3775 , TSI), which was operated by scanning the voltage of DMA2. For both DMA1 and DMA2, the aerosol flow rate was $0.3 \mathrm{~L} \mathrm{~min}^{-1}$ and the sheath-to-sample flow ratio was $10: 1$. The residence time of the monodisperse particles from the outlet of the humidifier to the inlet of DMA2, where the RH was considered to be $\sim 85 \%$, was approximately $11 \mathrm{~s}$. The sheath air flow of DMA2 was also humidified using another Nafion humidifier (PD-100T-12MSS, Perma Pure). The RH (temperature) measured (HMP237, Vaisala) at the inlets of aerosol flow and sheath flow to DMA2 were $85.0 \pm 0.2 \%\left(20.3 \pm 0.5^{\circ} \mathrm{C}\right)$ and $85.0 \pm 0.2 \%\left(20.4 \pm 0.5^{\circ} \mathrm{C}\right)$, respectively, and that at the outlet of the sheath flow of DMA2 was $86.0 \pm 0.3 \%\left(20.3 \pm 0.6^{\circ} \mathrm{C}\right)$. For analysis of the particle hygroscopic growth, RH of $85 \%$ was applied. The SMPS for the measurement of aerosol number-size distributions was composed of a third DMA (DMA3; 3080, 3081, TSI) and a CPC 3772 (TSI). The aerosol flow $(\mathrm{RH}<1.6 \%)$ was $0.3 \mathrm{~L} \mathrm{~min}^{-1}$ and the sheath to aerosol flow ratio was $10: 1$. At the inlet of CPC 3772 , the sample flow was diluted to $1 \mathrm{~L} \mathrm{~min}^{-1}$ with purified dry air, which was generated using a compressor (RD-45-N, IAC) and an air dryer (QD 3050 , IAC). The aerosol number-size distributions were measured for a dry diameter range of $13.8-749.9 \mathrm{~nm}$ every $5 \mathrm{~min}$. The performances of the three DMAs were assessed using standard size PSL particles before and after the observation (Sect. S1 in the Supplement). Furthermore, an aqueous solution of ammonium sulfate (AS) $(99.999 \%$ purity, SigmaAldrich) was nebulized and the generated aerosols were dried and introduced to the HTDMA, to assess the consistency of the sizing of the two DMAs under dry condition, and to validate the RH setting before the observation (Sect. S2). The setup and calibration procedures of the AMS were the same as those for the observations in 2014 (Deng et al., 2018). The V-mode (MS and PToF modes) data were analyzed using 
the Igor high-resolution data analysis package (PIKA1.20Q, Igor 6.37) to obtain the bulk and size-resolved mass concentrations of the chemical components (sulfate $\left(\mathrm{SO}_{4}\right)$, ammonium $\left(\mathrm{NH}_{4}\right)$, nitrate $\left(\mathrm{NO}_{3}\right)$, chloride $(\mathrm{Chl})$, and $\left.\mathrm{OA}\right)$, and the atomic ratios of $\mathrm{O}$ to $\mathrm{C}(\mathrm{O}: \mathrm{C}$ ratio) and $\mathrm{H}$ to $\mathrm{C}(\mathrm{H}: \mathrm{C}$ ratio) for organics. In addition, high-resolution bulk OA mass spectra observed in V-mode were subjected to PMF analysis (Paatero and Tapper, 1994; Ulbrich et al., 2009) (Sects. 3.3, S3). The RH of the sample flow was lower than $0.5 \%$.

A single-wavelength particle soot absorption photometer (1 $\lambda$-PSAP, $567 \mathrm{~nm}$, Radiance Research Inc.), with a thermodenuder maintained at $300^{\circ} \mathrm{C}$, was deployed to obtain the mass concentration of sub-micrometer black carbon (BC; Kondo et al., 2009; Deng et al., 2018). The mixing ratios of target gaseous species, $\mathrm{NO}-\mathrm{NO}_{2}-\mathrm{NO}_{x}, \mathrm{CO}, \mathrm{CO}_{2}$, and $\mathrm{O}_{3}$, were monitored using commercial instruments (APNA370 , Horiba, for $\mathrm{NO}-\mathrm{NO}_{2}-\mathrm{NO}_{x}$; model 48ij, Thermo Fisher Scientific, for CO; LI-820, LI-COR, for $\mathrm{CO}_{2}$; model 49ij, Thermo Fisher Scientific, for $\mathrm{O}_{3}$ ). Meteorological data were collected (Kyoto University, 2017). Air temperature, RH (HMP-155, Vaisala), precipitation (RH-5E, IKEDA-KEIKI), and solar radiation (CMP3-L, Campbell) were used in this study.

All the observation data except meteorological data were screened to eliminate data that might have been under the strong influence of local anthropogenic emissions, for example those from vehicles. This was performed by omitting data with spikes in the number concentrations of aerosols from their size distribution data, and in the mass concentration of BC (Sect. S4).

\section{Data analysis}

\subsection{Hygroscopicity of ambient aerosols}

The hygroscopic growth factor of aerosol particles, $g_{\mathrm{f}}$, was defined as the ratio of the particle wet diameter $\left(d_{\text {wet }}, 85 \%\right.$ $\mathrm{RH})$ to the corresponding dry diameter $\left(d_{\text {dry }}\right)$. The distributions of $g_{\mathrm{f}}$ for specific $d_{\text {dry }}\left(n\left(g_{\mathrm{f}}\right)\right.$, i.e., the number distribution of particles as a function of $g_{\mathrm{f}}$ ) were retrieved using the Twomey algorithm as presented by Mochida et al. (2010) with consideration of the shape of the transfer functions of the two DMAs. The difference in the processing is that the transfer function and the $n\left(g_{\mathrm{f}}\right)$ in this study were analyzed and presented in the fine mode of 1024 diameter bins per decade while 64 bins per decade were used in Mochida et al. (2010). The $g_{\mathrm{f}}$ probability distribution function, $g_{\mathrm{f}}-\mathrm{PDF}$, is the normalized $n\left(g_{\mathrm{f}}\right)$. The $g_{\mathrm{f}}-\mathrm{PDF}$ in this study is presented in linear scale, which was converted from the original logarithmic scale distribution. The time-resolved mean value of $g_{\mathrm{f}}$ for respective $d_{\mathrm{dry}}, g_{\mathrm{f}, \mathrm{m}}$, was calculated as follows.

$$
\begin{aligned}
g_{\mathrm{f}, \mathrm{m}} & =\frac{\sum n\left(g_{\mathrm{f}}\right) g_{\mathrm{f}}}{\sum n\left(g_{\mathrm{f}}\right)} \quad\left(0.8 \leq g_{\mathrm{f}} \leq 2.2 \text { for } 30 \leq d_{\mathrm{dry}}\right. \\
& \left.\leq 300 \mathrm{~nm}, \text { or } \quad 0.8 \leq g_{\mathrm{f}} \leq 2.0 \text { for } d_{\mathrm{dry}}=360 \mathrm{~nm}\right)
\end{aligned}
$$

For ambient particles, the time-resolved mean-water-volume equivalent $g_{\mathrm{f}}\left(g_{\mathrm{f}, \mathrm{mw}}\right.$, i.e., the average of $g_{\mathrm{f}}$ that corresponds to the mean water volume retained by particles of certain $d_{\text {dry }}$ ) was also calculated using Eq. (2) (Kawana et al., 2016).

$$
\begin{aligned}
& g_{\mathrm{f}, \mathrm{mw}}=\left[\frac{\sum n\left(g_{\mathrm{f}}\right)\left(g_{\mathrm{f}}^{3}-1\right)}{\sum n\left(g_{\mathrm{f}}\right)}+1\right]^{\frac{1}{3}} \\
& \left(0.8 \leq g_{\mathrm{f}} \leq 2.2 \text { for } 30 \leq d_{\mathrm{dry}} \leq 300 \mathrm{~nm},\right. \\
& \left.\quad \text { or } 0.8 \leq g_{\mathrm{f}} \leq 2.0 \text { for } d_{\text {dry }}=360 \mathrm{~nm}\right)
\end{aligned}
$$

The hygroscopicity parameter of ambient particles at $85 \%$ RH $\left(\kappa_{t}\right)$ was calculated following the $\kappa$-Köhler theory (Petters and Kreidenweis, 2007).

$\kappa_{t}=\left(g_{\mathrm{f}, \mathrm{mw}}^{3}-1\right)\left[\frac{\exp \left(\frac{4 \sigma M_{\mathrm{w}}}{\mathrm{RT} \rho_{\mathrm{w}} d_{\mathrm{wet}}}\right)}{0.85}-1\right]$,

where $\sigma$ is the surface tension at the solution-air interface; $M_{\mathrm{w}}$ and $\rho_{\mathrm{w}}$ are the molecular mass and density of pure water, respectively; $d_{\text {wet }}$ is the product of $g_{\mathrm{f}, \mathrm{mw}}$ and $d_{\mathrm{dry}} ; R$ is the universal gas constant; and $T$ is the temperature in kelvin. In this study, the mean temperature at the inlets of aerosol flow and sheath flow of DMA2, weighted by their flow rates, was applied as $T(294 \mathrm{~K})$ and the surface tension of pure water at this temperature (Vargaftik et al., 1983) was used as $\sigma$ in Eq. (3). Because $\kappa_{t}$ was calculated from $g_{\mathrm{f}, \mathrm{mw}}$, the aerosol mixing state was not considered in the analysis of $\kappa$ in this study.

\subsection{Hygroscopicity of $\mathrm{OA}$}

The hygroscopicity parameter of organics, $\kappa_{\text {org }}$, was calculated using Eq. (4) assuming the volume additivity of water retained by different aerosol components (Petters and Kreidenweis, 2007).

$$
\begin{aligned}
\kappa_{t} & =\varepsilon_{\mathrm{org}} \kappa_{\mathrm{org}}+\varepsilon_{\text {inorgsalt }} \kappa_{\text {inorgsalt }}+\varepsilon_{\mathrm{BC}} \kappa_{\mathrm{BC}} \\
& =\varepsilon_{\mathrm{org}} \kappa_{\mathrm{org}}+\sum_{i=1}^{5} \varepsilon_{\mathrm{i}} \kappa_{\mathrm{i}}+\varepsilon_{\mathrm{BC}} \kappa_{\mathrm{BC}}
\end{aligned}
$$

Here, $\kappa_{t}$ is the hygroscopicity parameter of ambient aerosol at $85 \%$ RH calculated using Eq. (3), while $\kappa_{\text {org }}, \kappa_{\text {inorgsalt }}$, and $\kappa_{\mathrm{BC}}$ are the hygroscopicity parameters of $\mathrm{OA}$, inorganic salts, and $\mathrm{BC}$, respectively. The volume fractions of OA, inorganic salts, and $\mathrm{BC}$ are $\varepsilon_{\mathrm{org}}, \varepsilon_{\text {inorgsalt }}$, and $\varepsilon_{\mathrm{BC}}$, respectively, and $\varepsilon_{i}$ and $\kappa_{i}$ are the volume fraction and hygroscopicity parameter of the inorganic salts: ammonium nitrate (AN), sulfuric acid 
(SA), ammonium hydrogen sulfate (AHS), letovicite (LET), and ammonium sulfate (AS). The $\varepsilon_{\mathrm{org}}, \varepsilon_{i}$, and $\varepsilon_{\mathrm{BC}}$ were calculated based on the size-resolved mass concentrations of organics, sulfate, nitrate, and ammonium from the AMS, and the sub-micrometer BC mass concentrations from the PSAP. $\mathrm{BC}$ was assumed to have the same mass-size distribution as $\mathrm{OA}$. The aerosol particles were assumed to be spherical and without voids. PToF mode data in vacuum aerodynamic diameter $\left(d_{\mathrm{va}}\right)$ ranges that were $\sim 1.0(0.98-0.99)$ to 2.0 times that of $d_{\text {dry }}$, corresponding to the particle density of $\sim 1.0$ $(0.98-0.99)$ to $2.0 \mathrm{~g} \mathrm{~cm}^{-3}$, were adopted. More details about the calculations of the size-resolved $\varepsilon_{\mathrm{org}}, \varepsilon_{i}$, and $\varepsilon_{\mathrm{BC}}$ are presented in Sect. S5. The derivation of $\kappa_{i}$ was based on the online Extended AIM Aerosol Thermodynamics Model II (E-AIM II, http://www.aim.env.uea.ac.uk/aim/kohler/input_ kohler.html, last access: 1 August 2018; Clegg et al., 1998; Wexler and Clegg, 2002) as presented in Sect. S6 and Table S3 in the Supplement. The $\kappa$ of BC was assumed to be zero. Because of the low signal intensity of the PToF data in the sub- $100 \mathrm{~nm} d_{\mathrm{va}}$ range (Sect. S7), the $\kappa_{\text {org }}$ was only derived for particles with $d_{\text {dry }}$ of $100,200,300$, and $360 \mathrm{~nm}$. Furthermore, to assess the influence of the choice of the $d_{\mathrm{va}}$ range on the derivation of $\kappa_{\mathrm{org}}$, the derived $\kappa_{\mathrm{org}}$ for particles with $d_{\text {dry }}$ of $100 \mathrm{~nm}$ using the chemical composition in the $d_{\mathrm{va}}$ range $98-197 \mathrm{~nm}$ was compared with that using the chemical composition in the $d_{\mathrm{va}}$ range $69-138 \mathrm{~nm}$ (Fig. S4 in the Supplement). The result indicates that $\kappa_{\text {org }}$ was not sensitive to change in the selected $d_{\mathrm{va}}$ range when $\varepsilon_{\text {org }}$ was greater than $40 \%$. Note that, although the volume additivity assumption between organics and inorganics may not necessarily hold (Vaishya et al., 2013; the $\kappa_{\text {org }}$ derived in the manner in this study represents the perturbation of $\kappa_{t}$ as a result of the presence of organics), the inverse linear correlation between $\kappa_{t}$ and $\varepsilon_{\text {org }}$ (correlation coefficients: -0.45 to -0.83 ; Fig. S5) suggests that the additivity holds well for the aerosols studied.

\subsection{PMF analysis of $\mathrm{OA}$ mass spectra}

To characterize the diurnal variations and size dependence of $\kappa_{\text {org }}$, the high-resolution OA bulk mass spectra derived from the V-mode AMS data were subjected to PMF analysis (Sect. S3), followed by derivation of the size-resolved contributions of the PMF factors to the OA mass concentration (Sect. S8). A two-factor PMF solution was adopted, which resolved two oxygenated OA factors: one with a lower atomic $\mathrm{O}: \mathrm{C}$ ratio $(0.47)$ named less-oxygenated organic aerosol (LOOA), and the other with a higher $\mathrm{O}: \mathrm{C}$ ratio (0.95) named more-oxygenated organic aerosol (MOOA). The low relative residual $(2.6 \%)$ for the bulk mass spectra supports the use of the two PMF factors to illustrate the observed OA. Note that the two OA factors resolved here represent two different groups of OA chemical structures, not necessarily two different OA sources (Zhang et al., 2011). The use of a PMF result with more factors could make illustration of the variation in $\kappa_{\text {org }}$ complex and was not adopted. The $\mathrm{PToF}$ mode OA mass spectra in $2 \mathrm{~h}$ time resolution were attributed to the two PMF factors through multivariable linear regression (Sect. S8). For particles with $d_{\text {dry }}$ equal to or larger than $100 \mathrm{~nm}$, the variation in $\kappa_{\text {org }}$ was discussed with regard to the variations in the two PMF factors. Furthermore, the hygroscopicity parameters for the two OA fractions were derived and then used to estimate the hygroscopicity of freshly formed BSOA (Sect. 4.2).

\section{Results and discussions}

\subsection{Overview of the observations}

\subsubsection{Meteorological conditions, gaseous species, and aerosol chemical composition}

During the measurement period with effective data, the mean \pm standard deviation (SD) of the temperature and $\mathrm{RH}$ of the ambient air were $18.2 \pm 2.4^{\circ} \mathrm{C}$ and $94.2 \pm 7.6 \%$, respectively. Precipitation events occurred intermittently during 1-3, 6-10, and 16-17 September (Fig. S7). Backward air mass trajectories (Fig. S9) generated using NOAA's HYSPLIT atmospheric transport and dispersion modeling system (Draxler and Hess, 1998) indicate that, apart from on 1 and 17 September, most of the air masses that arrived at the observation site had traveled from the Japan archipelago (and even from the Asian continent) within 5 days, and may have transported aged anthropogenic pollutants to the observation site. The mean $\pm \mathrm{SD}$ of the $\mathrm{BC}$ concentration during the entire study period was $0.07 \pm 0.06 \mu \mathrm{g} \mathrm{m}^{-3}$ (Fig. S7). The mean $\pm \mathrm{SD}$ of the mixing ratios of $\mathrm{CO}, \mathrm{NO}, \mathrm{NO}_{2}$, $\mathrm{NO}_{x}$, and $\mathrm{O}_{3}$ during the entire study period were $164 \pm 42$, $0.33 \pm 0.12,0.56 \pm 0.35,0.63 \pm 0.38$, and $11.5 \pm 8.4 \mathrm{ppb}$, respectively (Fig. S7). The concentration of $\mathrm{BC}$ was low, and the mixing ratios of $\mathrm{CO}$ and $\mathrm{NO}_{x}$ were modest. A daily maximum of BC appeared in the afternoon hours (Fig. 2), which, however, might have been caused by the charring of $\mathrm{OA}$ at the heating temperature of $300^{\circ} \mathrm{C}$. The mixing ratios of $\mathrm{CO}$ and $\mathrm{NO}_{x}$ tended to be relatively high during 10:00-22:00 JST (Fig. S8), which might have been caused by the transport of anthropogenic pollution to the surface site by enhanced vertical convection in the daytime. The concentration of $\mathrm{O}_{3}$ was substantial and presented obvious diurnal variation (Fig. S7). On average, $\mathrm{O}_{3}$ peaked during noon with the solar radiation (Fig. S8), indicating the occurrence of photochemical reactions during the daytime.

The time series of the mass concentrations of aerosol chemical components and aerosol number-size distributions are presented in Fig. 1. Among non-refractory aerosol chemical components derived from the AMS and $\mathrm{BC}$ derived from the PSAP (total concentration: $6.2 \pm 4.4 \mu \mathrm{g} \mathrm{m}^{-3}$ ), organics on average accounted for the largest fraction $(45.0 \%$, of which LOOA and MOOA accounted for $24.9 \%$ and $19.1 \%$, 
respectively), followed by sulfate $(39.6 \%)$ and ammonium $(11.6 \%)$. The contributions of nitrate, $\mathrm{BC}$, and chloride were minor: their mass fractions were on average $2.5 \%, 1.1 \%$, and $0.2 \%$, respectively. The contribution of $\mathrm{OA}$ to the submicrometer aerosol mass increased and that of sulfate decreased in the afternoon hours (12:00-20:00 JST). The mean aerosol number concentration $\left(N_{\mathrm{CN}}\right)$ was $1241 \pm 1012 \mathrm{~cm}^{-3}$. The geometric mean diameter of the aerosols ranged from 45 to $154 \mathrm{~nm}$ with a mean $\pm \mathrm{SD}$ of $88 \pm 17 \mathrm{~nm}$. No strong burst of small particles (i.e., $d_{\text {dry }}<30 \mathrm{~nm}$ ) was identified during the observation, which is different from the two former observations in 2010 and 2014 (Han et al., 2013; Deng et al., 2018).

The diurnal variation in the number-size distributions and the mass concentrations of the chemical components of aerosols are presented in Fig. 2. The $N_{\mathrm{CN}}$, OA, and LOOA presented similar diurnal variation patterns. Their daily minima were observed between 06:00 and 08:30 JST. After 08:30 JST, they increased monotonically and reached their maxima during 15:00-18:00 JST. Then they gradually decreased until approximately 06:00 JST of the next day. MOOA also increased slowly (following the trend of LOOA) in the daytime and reached its maximum around 18:00 JST. The pattern of the enhancement of OA in the daytime followed that of the solar radiation (Fig. 2b), indicating that the enhancement of OA was caused by the formation of BSOA through photochemical reactions of BVOC (Han et al., 2014; Deng et al., 2018). This is supported by an analysis indicating that anthropogenic pollution was not the main contributor to the enhancement of $\mathrm{OA}$, at least during the period 12:00-16:00 JST (Sect. S9), and by the report that primary biogenic OA is mainly in the supermicrometer aerosol diameter range in a forest environment, for the Amazon at least (Pöschl et al., 2010). Furthermore, the stronger enhancement of LOOA than of MOOA indicates that the freshly formed BSOA was mainly composed of LOOA and had a low oxygenation state. The $\mathrm{O}: \mathrm{C}$ ratio of $\mathrm{OA}$ increased slowly from around noon to midnight (Fig. 2c), together with the appearance of MOOA, indicating the aging of freshly formed BSOA (Han et al., 2014). Because of high-RH conditions (Fig. S7), aqueous-phase reactions including in-cloud processes could have played an important role in the aging of fresh BSOA (Han et al., 2014), which could have modified the hygroscopicity of ambient aerosols (Jimenez et al., 2009; Farmer et al., 2015). Although no abrupt increase in sub- $30 \mathrm{~nm}$ particles was observed, the increase in the number concentration of $30-50 \mathrm{~nm}$ particles around noon indicates the formation of new particles near the observation site. These particles had probably grown by the condensation of BSOA formed from BVOC at the time they were transported to the observation site. The concentrations of nitrate and chloride stayed low, although they also presented maxima in the afternoon. Sulfate, which may have been strongly influenced by transported anthropogenic aerosol, did not present an obvious diurnal variation. This result supports the view that the contribution of anthropogenic OA to the observed enhancement of OA was small.

\subsubsection{Hygroscopicity of atmospheric aerosols}

Similar to a prior observation at the same site in 2010 (Kawana et al., 2017), the hygroscopic growth factor $g_{\mathrm{f}}$ presented unimodal distributions at respective particle diameters (Figs. 1d, e, and S11), and the mean hygroscopic growth factor $g_{\mathrm{f}, \mathrm{m}}$ of the aerosols increased with an increase in the particle diameters (Fig. S12). The mean $\pm \mathrm{SD}$ of $g_{\mathrm{f}, \mathrm{m}}$ at $30,50,70,100,200,300$, and $360 \mathrm{~nm}$ were $1.13 \pm 0.08$, $1.21 \pm 0.09,1.22 \pm 0.09,1.26 \pm 0.10,1.36 \pm 0.10,1.40 \pm 0.08$, and $1.42 \pm 0.08$, respectively. The unimodal pattern of the $g_{\mathrm{f}}$-PDF indicated the internal mixing state of the observed aerosol at the respective particle diameters. Decreases in $g_{\mathrm{f}, \mathrm{m}}$ (Fig. S12) were observed for all particles during periods of intensive BSOA formation (i.e., episodes when the mass concentration of OA especially LOOA greatly increased; such episodes were observed on 31 August, and on 2, 5, 7, 9, 14, 15, 17, 18, 19, 20, and 21 September; Fig. 1b).

The hygroscopicity parameter of ambient aerosol particles that corresponds to $g_{\mathrm{f}, \mathrm{mw}}\left(\kappa_{t}\right)$ also increased with the increase in aerosol particle diameters (Fig. 3a). Similar diurnal variation patterns were observed for all the diameters studied. The $\kappa_{t}$ started to decrease around 08:00 JST, then reached daily minima between 13:00 and 19:00 JST. Then it increased continually until around 02:00 JST of the next day, and remained high until 08:00 JST the next morning. For particles with $d_{\mathrm{dry}} \geq 100 \mathrm{~nm}$, the diurnal variation pattern and size dependence of $\kappa_{t}$ were opposite to those of the volume fraction of OA (Fig. 3b) and were similar to those of the volume fraction of total inorganic salts (Fig. S13). The results suggest that, at least for ambient aerosol particles with $d_{\text {dry }} \geq 100 \mathrm{~nm}$, OA and inorganic salts had low and high hygroscopicity, respectively, and this resulted in the variations in $\kappa_{t}$. Although $\kappa_{\text {inorgsalt }}$ is much greater than $\kappa_{\mathrm{org}}$ (Petters and Kreidenweis, 2007), the high $\varepsilon_{\text {org }}$ makes the influence of OA on $\kappa_{t}$ significant. Thus, the variation in $\kappa_{\mathrm{org}}$ (Sect. 4.2) may also contribute to the variation in $\kappa_{t}$. For particles with $d_{\text {dry }} \leq 70 \mathrm{~nm}$, the decrease in the particle hygroscopicity with the decrease in the particle diameter is also explained by the accompanying increase in $\varepsilon_{\text {org }}$ and the decrease in $\varepsilon_{\text {inorgsalt }}$ (Levin et al., 2014). This is indicated by the substantially lower mean mass fraction of inorganic salts than of organics in the corresponding $d_{\mathrm{va}}$ range of less than $150 \mathrm{~nm}$ (Fig. S2). In particular, for particles with $d_{\text {dry }}$ of $30 \mathrm{~nm}, \kappa_{t}$ remained constant in a low range (0.079-0.089) from 13:00 to 17:00 JST with a mean value of 0.082. BSOA formed during this period probably dominated the particle mass (Kawana et al., 2017; Han et al., 2014). 


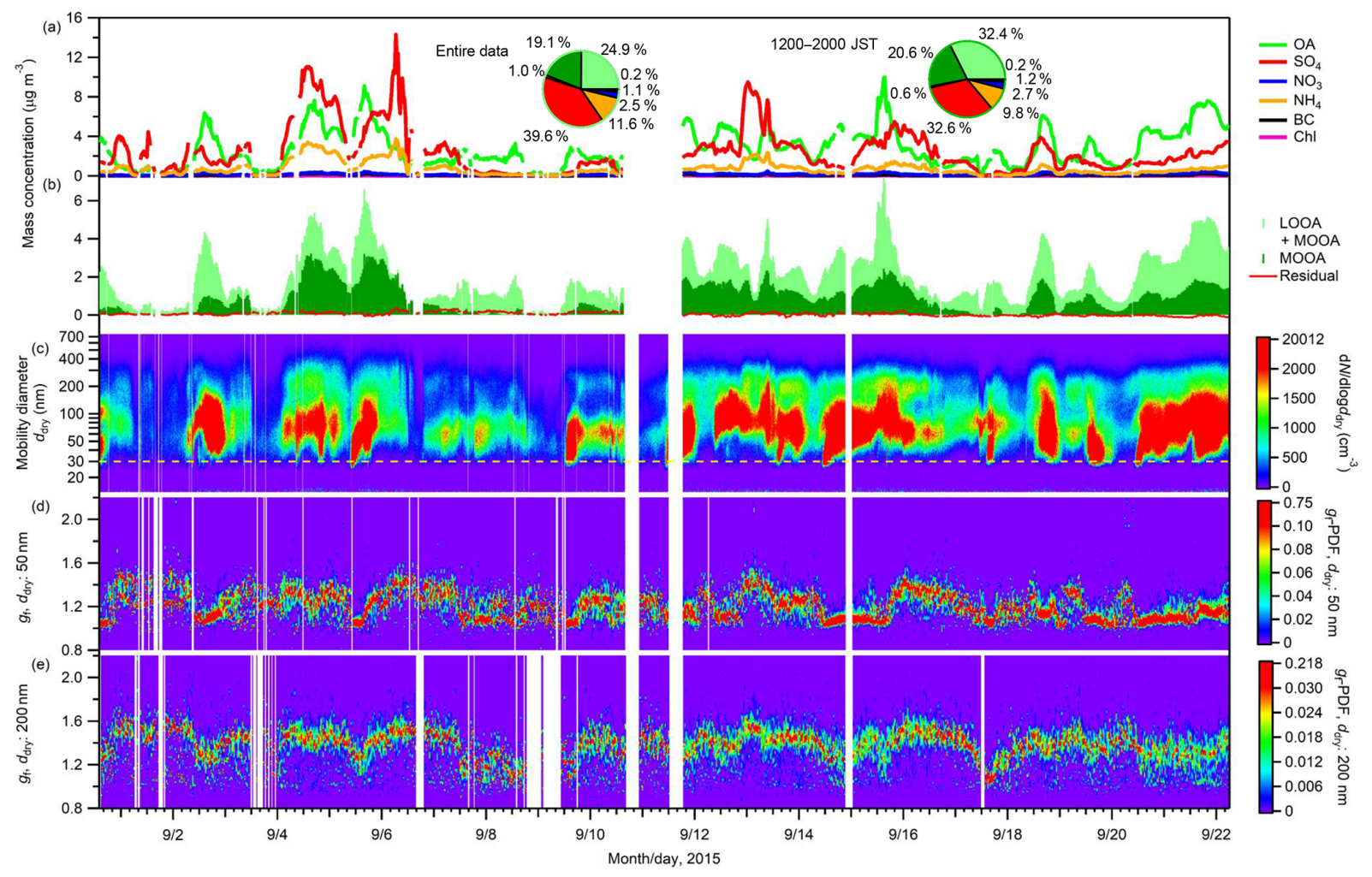

Figure 1. Time series of (a) sub-micrometer mass concentrations of non-refractory aerosol chemical components $\left(\mathrm{OA}, \mathrm{SO}_{4}, \mathrm{NO}_{3}, \mathrm{NH}_{4}\right.$, and Chl) from the AMS measurement and BC from the PSAP measurement; (b) mass concentrations of LOOA and MOOA, and the residuals from the PMF analysis; (c) aerosol number-size distributions; and $g_{\mathrm{f}}$-PDF of aerosol particles with $d_{\text {dry }}$ of (d) 50 and (e) $200 \mathrm{~nm}$. The two pie charts in panel (a) present the mass fractions of chemical components for the entire study period and for the afternoon hours (12:0020:00 JST) during the study period. The dashed line in panel (c) represents a diameter of $30 \mathrm{~nm}$.

\subsection{Hygroscopicity of organic aerosol components}

\subsubsection{Variation in $\kappa_{\text {org }}$ and its relation to the chemical structure of $\mathrm{OA}$}

The diurnal variation in $\kappa_{\text {org }}$ and the volume fraction of LOOA in OA, $v_{\mathrm{LOOA}} /\left(v_{\mathrm{LOOA}}+v_{\mathrm{MOOA}}\right)$, where $v_{\mathrm{LOOA}}$ and $v_{\text {MOOA }}$ refer to the volume concentrations of LOOA and MOOA, respectively, for the entire study period are presented in Fig. 4. Data with $\varepsilon_{\text {org }}<0.40$ were excluded from the $\kappa_{\text {org }}$ values presented because the uncertainty that originated from subtraction of the contribution of inorganic components was considered large in the low $\varepsilon_{\text {org }}$ range (Mei et al., 2013a). The $\kappa_{\text {org }}$ decreased rapidly from approximately 08:00 JST in the morning when the mass concentrations of OA and LOOA started to increase (Fig. 2). The $\kappa_{\text {org }}$ reached daily minima during 10:00-18:00 JST and increased after the minima (Fig. $4 \mathrm{a})$. The $v_{\mathrm{LOOA}} /\left(v_{\mathrm{LOOA}}+v_{\mathrm{MOOA}}\right)$ in Fig. $4 \mathrm{~b}$ presents the opposite diurnal variation pattern. The characteristics of the size dependence of $\kappa_{\text {org }}$ and $v_{\text {LOOA }} /\left(v_{\text {LOOA }}+v_{\text {MOOA }}\right)$ were dependent on time periods. To characterize the size dependence of $\kappa_{\text {org }}$ and $v_{\mathrm{LOOA}} /\left(v_{\mathrm{LOOA}}+v_{\mathrm{MOOA}}\right)$, the mean values of $\kappa_{\text {org }}$ and $v_{\mathrm{LOOA}} /\left(v_{\mathrm{LOOA}}+v_{\mathrm{MOOA}}\right)$ during 12:00-20:00 and 20:00-12:00 JST were plotted separately in the $\kappa_{\text {org }}-$ $v_{\mathrm{LOOA}} /\left(v_{\mathrm{LOOA}}+v_{\mathrm{MOOA}}\right)$ space for different $d_{\text {dry }}$ (Fig. 5), and the difference in the diurnal variation data between particles with different diameters were evaluated using a $10 \%$ two-sided $t$ test (Table S7). During 12:00-20:00 JST, opposite size dependences were observed between the mean $\kappa_{\text {org }}$ and $v_{\mathrm{LOOA}} /\left(v_{\mathrm{LOOA}}+v_{\mathrm{MOOA}}\right)$. Although the differences in $\kappa_{\text {org }}$ between 200 and $300 \mathrm{~nm}$ particles ( $p$ value: 0.71 ) and 300 and $360 \mathrm{~nm}$ particles ( $p$ value: 0.15 ) were not significant, the differences in $\kappa_{\text {org }}$ between 100 and $200 \mathrm{~nm}$ particles ( $p$ value: 0.01 ) and 200 and $360 \mathrm{~nm}$ particles ( $p$ value: $0.07)$, and the differences in $v_{\mathrm{LOOA}} /\left(v_{\mathrm{LOOA}}+v_{\mathrm{MOOA}}\right)$ between particles with all different diameters ( $p$ value: $<0.02$ ), were significant during that period. During 20:00-12:00 JST, the size dependences of $\kappa_{\text {org }}$ and $v_{\mathrm{LOOA}} /\left(v_{\mathrm{LOOA}}+v_{\mathrm{MOOA}}\right)$ were not clear. The clearer size dependence of both $\kappa_{\text {org }}$ and $v_{\text {LOOA }} /\left(v_{\text {LOOA }}+v_{\text {MOOA }}\right)$ during 12:00-20:00 JST than during 20:00-12:00 JST was explained by the formation of BSOA during the afternoon hours. The patterns of diurnal variation and of size dependence between $\kappa_{\text {org }}$ and $v_{\text {LOOA }} /\left(v_{\text {LOOA }}+v_{\text {MOOA }}\right)$ during 12:00-20:00 JST indicate that the variation in $\kappa_{\text {org }}$ could be explained at least in part by the relative contributions of LOOA and MOOA to OA. That 


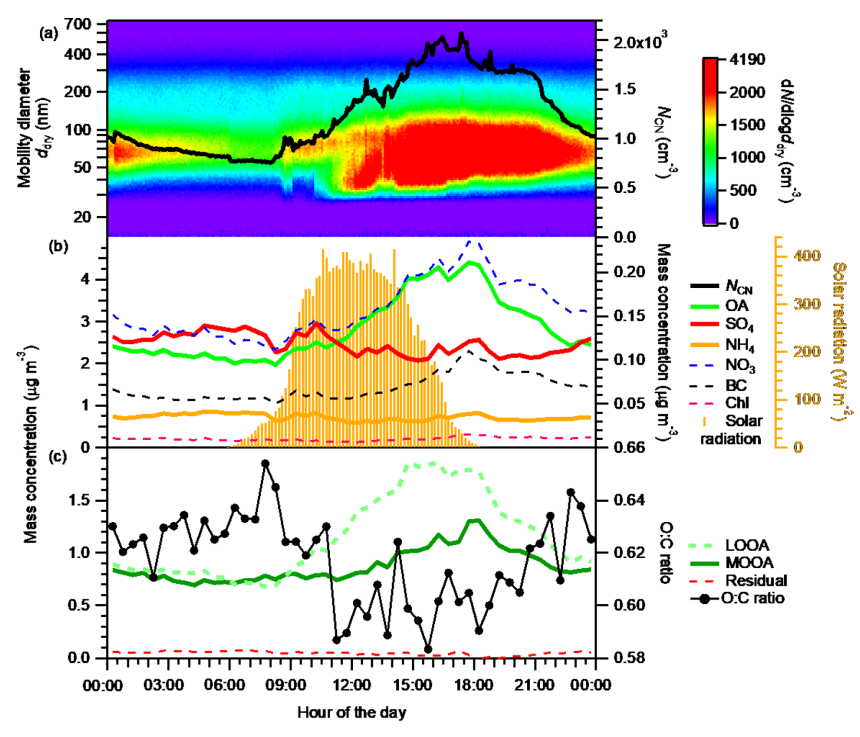

Figure 2. Diurnal variations in (a) number-size distribution (image plot) and number concentration ( $\mathrm{NCN}$, right axis) of ambient aerosols; (b) the mass concentrations of $\mathrm{OA}, \mathrm{SO}_{4}$, and $\mathrm{NH}_{4}$ (left axis), and $\mathrm{NO}_{3}, \mathrm{BC}$, and $\mathrm{Chl}$ (right axis in black); and (c) the mass concentrations of LOOA, MOOA, and the residual, and the $\mathrm{O}: \mathrm{C}$ ratio of bulk OA (only data with $m_{\mathrm{org}}>0.3 \mathrm{mg} \mathrm{m}^{-3}$ are included). (A box-and-whisker plot of the diurnal variation in $\mathrm{O}: \mathrm{C}$ ratio is presented in Fig. S19.) The diurnal variation in solar radiation is superimposed in panel (b). All data presented are averages for the entire study period.

is, the presence of LOOA with low oxygenation state $(\mathrm{O}: \mathrm{C}$ ratio of 0.47$)$ lowered the observed $\kappa_{\text {org }}$, while the presence of MOOA with high oxygenation state $(\mathrm{O}: \mathrm{C}$ ratio of 0.95$)$ increased the observed $\kappa_{\text {org }}$. A similar relationship was observed in a former study at the observation site: $\kappa_{\text {org }}$ was positively correlated with the $\mathrm{O}: \mathrm{C}$ ratio of the organics (Deng et al., 2018).

The hygroscopicity parameters of LOOA $\left(\kappa_{\mathrm{LOOA}}\right)$ and MOOA ( $\left.\kappa_{\text {MOOA }}\right)$ were determined to evaluate the variations in $\kappa_{\text {org }}$ that can be explained by the relative contributions of LOOA and MOOA to OA. For the determination of $\kappa_{\mathrm{LOOA}}$ and $\kappa_{\mathrm{MOOA}}, \kappa_{\mathrm{Org}}$ was plotted against $v_{\text {LOOA }} /\left(v_{\text {LOOA }}+v_{\text {MOOA }}\right)$ and their correlation was analyzed based on linear regression analysis (Figs. 5 and S14). For particles with $d_{\text {dry }}$ of $100,200,300$, and $360 \mathrm{~nm}$, the correlation coefficients between $\kappa_{\mathrm{Org}}$ and $v_{\mathrm{LOOA}} /\left(v_{\mathrm{LOOA}}+v_{\mathrm{MOOA}}\right)$ were $-0.50,-0.58,-0.27$, and -0.099 , respectively. Relatively high correlations were observed for particles with $d_{\text {dry }}$ of 100 and $200 \mathrm{~nm}$, probably because higher particle number concentrations (Fig. 1c) and higher OA volume fractions (Fig. 3) led to smaller uncertainties in the derived $\kappa_{\text {org }}$ in those diameter ranges than in those of 300 and $360 \mathrm{~nm}$. The regression line for particles with $d_{\text {dry }}$ of both 100 and $200 \mathrm{~nm}$ (Fig. 5) were used to derive $\kappa_{\mathrm{LOOA}}$ and $\kappa_{\mathrm{MOOA}}$ by applying $v_{\mathrm{LOOA}} /\left(v_{\mathrm{LOOA}}+v_{\mathrm{MOOA}}\right)$ of zero and unity to the obtained regression equation, respectively. The derived $\kappa_{\mathrm{LOOA}}$ and $\kappa_{\mathrm{MOOA}}$ were 0.083 and 0.28 , respectively. This result is in between the results if particles with $d_{\text {dry }}$ of only $100 \mathrm{~nm}$ (derived $\kappa_{\mathrm{LOOA}}$ and $\kappa_{\mathrm{MOOA}}$ were 0.060 and 0.25 , respectively) and only $200 \mathrm{~nm}$ (derived $\kappa_{\mathrm{LOOA}}$ and $\kappa_{\mathrm{MOOA}}$ were 0.095 and 0.34 , respectively) were used. Compared with the $\kappa$ of PMF factors reported by Jimenez et al. (2009), the derived $\kappa_{\mathrm{LOOA}}$ and $\kappa_{\mathrm{MOOA}}$ are within the ranges of $\kappa$ for semivolatile oxygenated OA (0.04-0.18) and low-volatility oxygenated OA (0.18-0.35), respectively (Fig. 5). The sizeresolved $v_{\mathrm{LOOA}} /\left(v_{\mathrm{LOOA}}+v_{\mathrm{MOOA}}\right)$ and the above derived $\kappa_{\mathrm{LOOA}}$ and $\kappa_{\mathrm{MOOA}}$ were used to reconstruct the diurnal variation data and mean values of size-resolved $\kappa_{\text {org }}$ during 12:0020:00 JST based on the volume additivity assumption. The reconstructed $\kappa_{\text {org }}$ and the $\kappa_{\text {org }}$ described above (measured $\kappa_{\text {org }}$ ) were compared and their correlations were evaluated through linear regression analysis (Fig. S15). The slope and $r^{2}$ of the regression line are used to assess the ability of LOOA and MOOA to explain the variations in $\kappa_{\text {org }}$. For 100 and $200 \mathrm{~nm}$ particles, the relative contribution of LOOA and MOOA to OA can explain the majority of the variations in $\kappa_{\text {org }}$ (the slope and $r^{2}$ for $100 \mathrm{~nm}$ particles were 0.72 and 0.79 , respectively, and those for $200 \mathrm{~nm}$ particles were 0.63 and 0.68 , respectively). The variations in $\kappa_{\text {org }}$ of 300 and $360 \mathrm{~nm}$ particles are explained less by the relative contributions of LOOA and MOOA to OA (the slope and $r^{2}$ for $300 \mathrm{~nm}$ particles were 0.31 and 0.48 , respectively; for $360 \mathrm{~nm}$ particles were 0.16 and 0.07 , respectively). The slope and $r^{2}$ of the regression line between reconstructed and measured $\kappa_{\text {org }}$ for particles with all four $d_{\text {dry }}$ were 0.39 and 0.44 , respectively. This result indicates that the relative contribution of LOOA and MOOA can explain around $40 \%$ of the observed diurnal variations in $\kappa_{\text {org }}$. The slope and $r^{2}$ of the regression line over the mean reconstructed and observed $\kappa_{\text {org }}$ of the four different sizes during afternoon hours (12:0020:00 JST) were 0.39 and 0.84 , respectively, which indicates that the size dependence of $\kappa_{\text {org }}$ is explained by the relative contribution of LOOA and MOOA to OA by at least $~ 40 \%$ during the time period.

\subsubsection{Hygroscopicity of biogenic secondary organic aerosols}

The hygroscopicity parameter of freshly formed BSOA $\left(\kappa_{\mathrm{BSOA}}\right)$ was calculated as the volume-weighted mean of $\kappa_{\mathrm{LOOA}}$ and $\kappa_{\mathrm{MOOA}}$. As discussed in Sect. 4.1.1, the enhanced OA mass in the daytime can be regarded as fresh BSOA. To simplify the analysis, the remaining part of the observed OA can be regarded as regionally transported OA (ROA), which may contain some aged, locally formed BSOA (Deng et al., 2018). To estimate the size-resolved contributions of LOOA and MOOA to BSOA and ROA, the size-resolved diurnal variations in sulfate were assumed to be a tracer of regionally transported aerosol and were scaled to represent the diurnal variations in LOOA and MOOA that constitute ROA (LOOA-ROA and MOOA-ROA; 


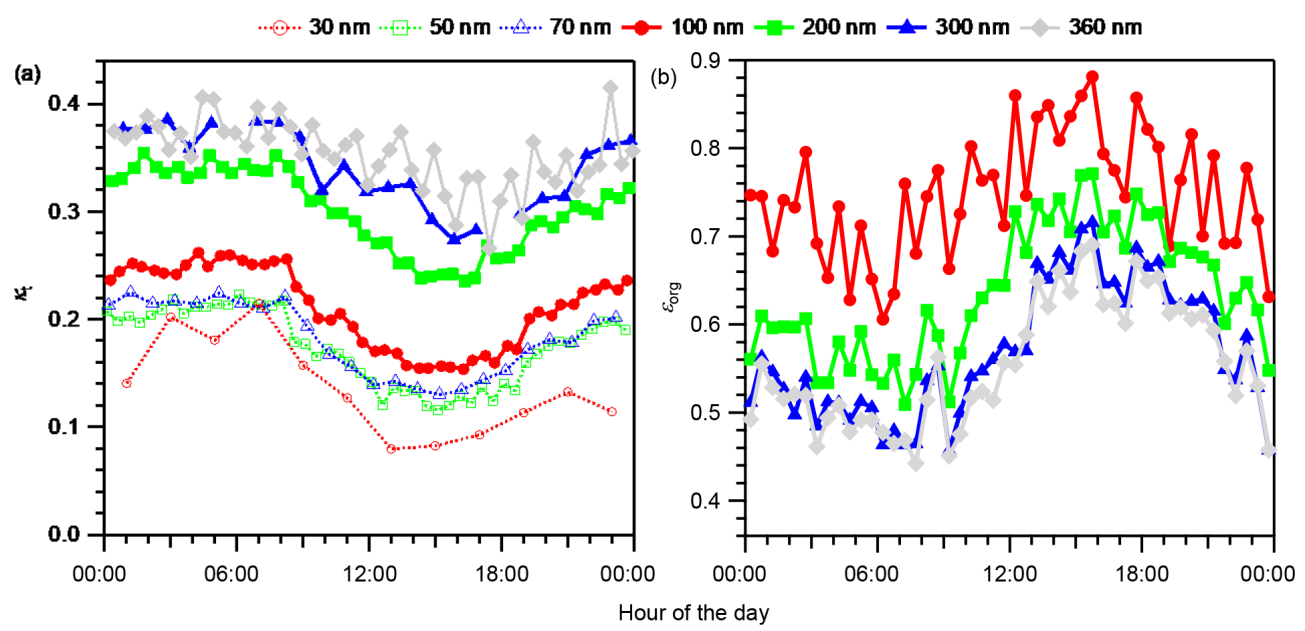

Figure 3. Diurnal variations in (a) size-resolved hygroscopicity of aerosols $\left(\kappa_{t}\right)$ and (b) size-resolved volume fractions of OA $\left(\varepsilon_{\text {org }}\right)$ for the entire study period. Note that for particles with $d_{\text {dry }}$ of $30 \mathrm{~nm}, \kappa_{t}$ is presented in $2 \mathrm{~h}$ time resolution because of the low data coverage (Fig. S12).

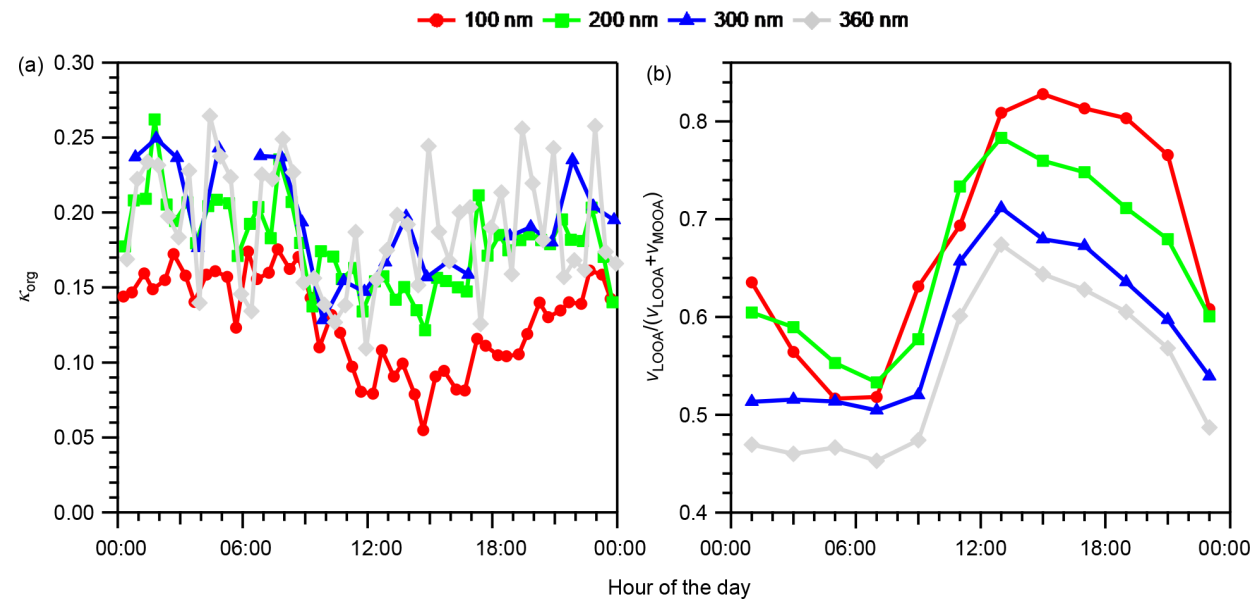

Figure 4. Diurnal variations in (a) size-resolved hygroscopicity of OA $\left(\kappa_{\mathrm{org}}\right)$ and (b) size-resolved volume fractions of LOOA in OA $\left(v_{\mathrm{LOOA}} /\left(v_{\mathrm{LOOA}}+v_{\mathrm{MOOA}}\right)\right)$ for the entire study period. For $\kappa_{\text {org }}$ in panel (a), only data with $\varepsilon_{\text {org }}>0.40$ were considered. The values in panel (b) were calculated from the diurnal variations in the average volume concentrations of LOOA and MOOA (Fig. S16), not from the averages of $v_{\mathrm{LOOA}} /\left(v_{\mathrm{LOOA}}+v_{\mathrm{MOOA}}\right)$.

Fig. S16). For the scaling, the period of 06:00-08:00 JST, when OA and its subcomponents reached their daily minima (Figs. 2 and S16), was regarded as the background period, and all the LOOA and MOOA during the period were considered constituents of ROA. The remaining fractions of LOOA and MOOA were regarded as constituents of BSOA, referred to as LOOA-BSOA and MOOA-BSOA, respectively. The $v_{\mathrm{LOOA}} /\left(v_{\mathrm{LOOA}}+v_{\mathrm{MOOA}}\right)$ of ROA was estimated to be $0.52,0.53,0.50$, and 0.45 for particles with $d_{\text {dry }}$ of $100,200,300$, and $360 \mathrm{~nm}$, respectively (the range is presented by the area filled with a left-slash pattern in Fig. 5). The period when the diurnal variations in the sizeresolved concentration of LOOA reached their maxima (i.e., 14:00-16:00 JST; Fig. S16) was chosen to estimate the size- resolved $v_{\text {LOOA }} /\left(v_{\text {LOOA }}+v_{\text {MOOA }}\right)$ of BSOA. The estimated $v_{\text {LOOA }} /\left(v_{\text {LOOA }}+v_{\text {MOOA }}\right)$ values of the BSOA were 0.97 , $0.88,0.80$, and 0.79 for particles with $d_{\text {dry }}$ of 100,200 , 300 , and $360 \mathrm{~nm}$, respectively (the range is presented by the area filled with a right-slash pattern in Fig. 5). Although the estimated BSOA could have aged to some extent, it was defined as fresh BSOA. The $\kappa_{\mathrm{BSOA}}$ (and $\kappa_{\mathrm{ROA}}$ ) values were calculated using the derived $v_{\mathrm{LOOA}} /\left(v_{\mathrm{LOOA}}+v_{\mathrm{MOOA}}\right)$ of BSOA (ROA) for particles with different $d_{\mathrm{dry}}$ and $\kappa_{\mathrm{LOOA}}$ and $\kappa_{\mathrm{MOOA}}$, and found to be $0.089(0.18), 0.11(0.18)$, $0.12(0.18)$, and $0.12(0.19)$ for particles with $d_{\text {dry }}$ of 100 , 200,300 , and $360 \mathrm{~nm}$, respectively. The result indicates that $\kappa_{\mathrm{BSOA}}$ may increase with an increase in the particle diameter as a result of the size-dependent contribution of LOOA 


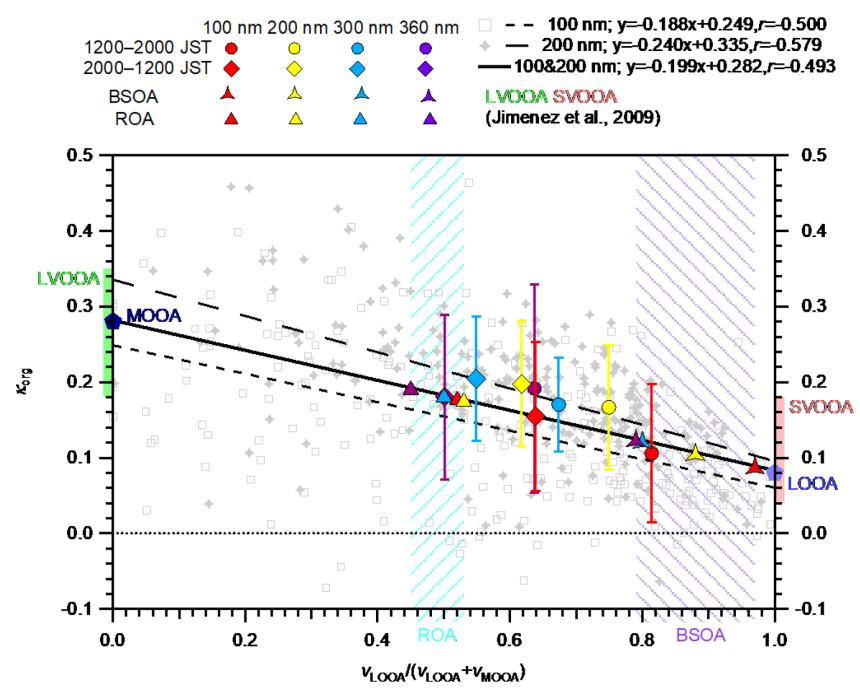

Figure 5. $\kappa_{\text {org }}$ versus $v_{\text {LOOA }} /\left(v_{\text {LOOA }}+v_{\text {MOOA }}\right)$ for particles with $d_{\text {dry }}$ of $100 \mathrm{~nm}$ (gray open squares) and $200 \mathrm{~nm}$ (gray cross markers) over the entire study period. The time resolution of individual data is $2 \mathrm{~h}$. Only data with $\varepsilon_{\text {org }}>0.40$ are considered. The shortdashed, long-dashed, and solid lines are the regression lines for particles with $d_{\text {dry }}$ of $100,200 \mathrm{~nm}$, and the sum of the particles with the two sizes, respectively. The $\kappa$ values of LOOA and MOOA derived from the regression lines (Sect. 4.2.1) are indicated by the light and dark blue pentagons, respectively. The size-resolved mean $\kappa_{\text {org }}$ values during 12:00-20:00 and 20:00-12:00 JST are indicated as filled circles and diamond markers, respectively. The standard deviations of the mean $\kappa_{\text {org }}$ are indicated by the whiskers. The standard deviations of the mean $v_{\mathrm{LOOA}} /\left(v_{\mathrm{LOOA}}+v_{\mathrm{MOOA}}\right)$ are presented in Table S6. The size-resolved $\kappa$ values of BSOA and ROA are indicated by the three-pointed stars and triangles, respectively. The diameters of $\kappa_{\mathrm{Org}}, \kappa_{\mathrm{BSOA}}$, and $\kappa_{\mathrm{ROA}}$ are differentiated by colors. The ranges of $\kappa$ for low-volatility oxygenated OA (LVOOA) and semivolatile oxygenated OA (SVOOA) from Jimenez et al. (2009) are superimposed on the left and right axes, respectively. The shaded areas represent the estimated ranges of $v_{\mathrm{LOOA}} /\left(v_{\mathrm{LOOA}}+v_{\mathrm{MOOA}}\right)$ for ROA (left slash pattern) and BSOA (right slash pattern) of 100-360 nm particles.

and MOOA to BSOA (Fig. 5; colored three-pointed stars), which, however, needs to be confirmed by further studies. The size dependence of the estimated $\kappa_{\text {ROA }}$ (Fig. 5; colored triangles) was less obvious than that of $\kappa_{\mathrm{BSOA}}$. The $\kappa_{\mathrm{BSOA}}$ derived at $85 \% \mathrm{RH}$ for particles with $d_{\mathrm{dry}}$ of $100 \mathrm{~nm}$ in this study (0.089) was slightly smaller than that in a previous study for particles with similar diameters under SUPS $(0.10$ at $94 \pm 11 \mathrm{~nm})$ at the same site (Deng et al., 2018). The derived $\kappa_{\mathrm{ROA}}$ is similar to the average $\kappa_{\text {org }}$ during the nighttime (Fig. 4). The size-resolved volume concentrations of BSOA $\left(v_{\mathrm{BSOA}}\right)$ and ROA ( $\left.v_{\mathrm{ROA}}\right)$ were also estimated using those size-resolved $v_{\text {LOOA }} /\left(v_{\text {LOOA }}+v_{\text {MOOA }}\right)$ values of BSOA and ROA (Sect. S10). The obtained volume fraction of BSOA in aerosol particles $\left(\varepsilon_{\mathrm{BSOA}}\right.$; Fig. S18) presented diurnal variation patterns that were similar to those of $v_{\text {LOOA }} /\left(v_{\text {LOOA }}+v_{\text {MOOA }}\right)$. Furthermore, the size dependence of $\varepsilon_{\mathrm{BSOA}}$ during afternoon hours was also similar to that of $v_{\text {LOOA }} /\left(v_{\text {LOOA }}+v_{\text {MOOA }}\right)$. Because both the volume concentrations and hygroscopicity of BSOA and ROA were derived from that of LOOA and MOOA, the variation in the relative contributions of the estimated BSOA and ROA to OA can explain $40 \%$ of the diurnal variation and size dependence of the measured $\kappa_{\text {org }}$.

\subsection{Ranges of the variations in $\kappa_{t}, \kappa_{\mathrm{org}}$, and $\kappa_{\mathrm{BSOA}}$}

The ranges of the diurnal variations in $\kappa_{t}$ and $\kappa_{\text {org }}$, the difference between their maxima and minima, were obtained from their diurnal variation data with $2 \mathrm{~h}$ resolution (Table S8). The variation ranges of $\kappa_{t}$ were $0.14,0.091,0.084,0.10$, $0.11,0.11$, and 0.070 for particles with $d_{\text {dry }}$ of $30,50,70$, $100,200,300$, and $360 \mathrm{~nm}$, respectively. The variation ranges of $\kappa_{\mathrm{org}}$ for particles with $d_{\mathrm{dry}}$ of $100,200,300$, and $360 \mathrm{~nm}$ were $0.091,0.079,0.096$, and 0.11 , respectively. The size dependence of $\kappa_{t}$ and $\kappa_{\mathrm{org}}$ were quantified by the mean $\kappa_{t}$ and $\kappa_{\text {org }}$ values for the entire study period (Table S8). The difference in $\kappa_{t}$ between particles with $d_{\text {dry }}$ of 100 and $300 \mathrm{~nm}$ was 0.13 , and that of $\kappa_{\text {org }}$ was 0.056 .

The ranges of both the diurnal variations and the size dependence of $\kappa_{t}$ are similar to those reported from a previous study at the same site in 2010 (the mean of the differences between 09:00-21:00 and 21:00-09:00 JST on NPF event days and on nonevent days for the $d_{\text {dry }}$ range of $28.9-359 \mathrm{~nm}$ was in the range of 0.09-0.13, and the difference between Aitken mode and accumulation mode particles was 0.12) (Kawana et al., 2017), which pointed out the importance of the variation in particle hygroscopicity with time and size to the CCN number concentration. The ranges of both the diurnal variations and the size dependence of $\kappa_{\text {org }}$ are comparable to the range of 0.05 (from 0.08 to 0.13 ) that could lead to $30 \%$ or more bias in the predicted CCN number concentration if not considered (Mei et al., 2013b). Here, only the ranges of the variation in $\kappa_{t}$ and $\kappa_{\text {org }}$ are discussed; other factors such as the absolute values of $\kappa_{t}$ or $\kappa_{\text {org }}$ should also be important to the prediction of $\mathrm{CCN}$ number concentrations. If SS is $0.1 \%-1 \%$, typical maximum values in cloud systems (Farmer et al., 2015), the $d_{\text {dry }}$ of $100 \mathrm{~nm}$ is close to the mode diameters of the CCN number-size distributions in previous studies at the same site (Kawana et al., 2017; Deng et al., 2018), whereas the $d_{\mathrm{dry}}$ of $300 \mathrm{~nm}$ is close to the mode mobility diameters of the mass-size distributions of OA and other aerosol components in this study (Fig. S2). The difference in the two types of mode diameters indicates that significant bias could be introduced if the bulk aerosol composition and/or OA composition is used for the prediction of $\mathrm{CCN}$ number concentrations.

The difference in the estimated $\kappa_{\mathrm{BSOA}}$ between particles with $d_{\text {dry }}$ of 100 and $300 \mathrm{~nm}$ was estimated to be 0.031 . The difference implies the importance of the size dependence of 
$\kappa_{\mathrm{BSOA}}$ in the prediction of the contribution of BSOA to the $\mathrm{CCN}$ number concentration.

\subsection{Contributions of $\mathrm{OA}$ and BSOA to $\mathrm{CCN}$ concentrations}

The contributions of OA and BSOA to $\mathrm{CCN}$ number concentrations were assessed from the viewpoint of their contributions to the aerosol water uptake, which are size-dependent. For the estimate, the observed aerosols were assumed to be internally mixed. This is supported by a result from a previous study at the observation site: there was almost no difference in the prediction of the number fractions of $\mathrm{CCN}$ between the use of time- and size-resolved $g_{\mathrm{f}}$ distributions and time- and size-resolved $g_{\mathrm{f}, \mathrm{m}}$ (Kawana et al., 2017). The CCN activation diameters $\left(d_{\text {act }}\right)$ for respective $2 \mathrm{~h}$ time-of-day bins at $0.4 \% \mathrm{SS}$ were calculated from reconstructed hygroscopicity parameter values of aerosol particles based on $\kappa$-Köhler theory (Sect. S11). The estimated total CCN number concentration is referred to as $N_{\mathrm{CCN}, t}$. For each size range, the contribution of OA (BSOA) to the aerosol water uptake was represented as the product of the volume fraction of OA (BSOA) and $\kappa_{\text {org }}\left(\kappa_{\mathrm{BSOA}}\right)$ divided by $\kappa_{t}$ (i.e., $\varepsilon_{\mathrm{org}} \kappa_{\mathrm{org}} / \kappa_{t}$ $\left.\left(\varepsilon_{\mathrm{BSOA}} \kappa_{\mathrm{BSOA}} / \kappa_{t}\right)\right)$ and was used to represent the fractional contribution of OA (and BSOA) to $\mathrm{d} N_{\mathrm{CN}} / \mathrm{d} \log d_{\mathrm{dry}}$ in the size range. The fractional contribution of OA (and BSOA) to $N_{\mathrm{CCN}, t}$, hereafter referred to as $F_{\mathrm{CCN}, \mathrm{OA}}\left(F_{\mathrm{CCN}, \mathrm{BSOA}}\right)$, was derived by integrating the product of $\mathrm{d} N_{\mathrm{CN}} / \mathrm{d} \log d_{\mathrm{dry}}$ and $\varepsilon_{\mathrm{org}} \kappa_{\mathrm{Org}} / \kappa_{t}\left(\varepsilon_{\mathrm{BSOA}} \kappa_{\mathrm{BSOA}} / \kappa_{t}\right)$ above the $d_{\mathrm{act}}$ and by dividing the obtained value by $N_{\mathrm{CCN}, t}$. Details for the estimation of $F_{\mathrm{CCN}, \mathrm{OA}}$ and $F_{\mathrm{CCN}, \mathrm{BSOA}}$ are presented in Sect. S11.

The diurnal variation in $F_{\mathrm{CCN}, \mathrm{OA}}$ estimated using timeand size-resolved $\kappa_{\mathrm{org}}$ and that of $F_{\mathrm{CCN}, \mathrm{BSOA}}$ using sizeresolved $k_{\mathrm{BSOA}}$ are presented in Fig. 6 . Both $F_{\mathrm{CCN}, \mathrm{OA}}$ and $F_{\mathrm{CCN}, \mathrm{BSOA}}$ reached their maxima during 12:00-16:00 JST, when intensive BSOA formation was observed. The magnitude of the variation in $F_{\mathrm{CCN}, \mathrm{BSOA}}$ (from 0.00 to 0.28 ) was larger than that of $F_{\mathrm{CCN}, \mathrm{OA}}$ (from 0.40 to 0.52 ). This is explained by the larger magnitude of the diurnal variation range of $\varepsilon_{\mathrm{BSOA}}$ (Fig. S18), compared to that of $\varepsilon_{\text {org }}$ (Fig. 3). The $F_{\mathrm{CCN}, \mathrm{BSOA}}$ of 0.28 during 14:00-16:00 JST indicates a significant contribution of BSOA to the $\mathrm{CCN}$ number concentration.

Because obvious diurnal variations and size dependence of $\kappa_{\mathrm{org}}$ were found and because $\kappa_{\mathrm{BSOA}}$ was also estimated to be size-dependent (Sect. 4.2), the sensitivities of the estimated $F_{\mathrm{CCN}, \mathrm{OA}}$ and $F_{\mathrm{CCN}, \mathrm{BSOA}}$ on the variations in $\kappa_{\mathrm{org}}$ and $\kappa_{\mathrm{BSOA}}$ were assessed. To assess the influence of the variation in $\kappa_{\text {org }}$ on $F_{\mathrm{CCN}, \mathrm{OA}}$, the diurnal variations in $F_{\mathrm{CCN}, \mathrm{OA}}$ were estimated using ( 0 a, base case) time- and size-resolved $\kappa_{\text {org }}$; (1a) size-resolved, time-averaged (note that the average here refers to the arithmetic mean, and it is the same in other places of this paragraph) $\kappa_{\text {org }}$; (2a) time-resolved, size-averaged $\kappa_{\text {org }}$; and (3a) time- and size-averaged $\kappa_{\text {org }}$ (Table S10). Cases (1a)-(3a) were compared with the base

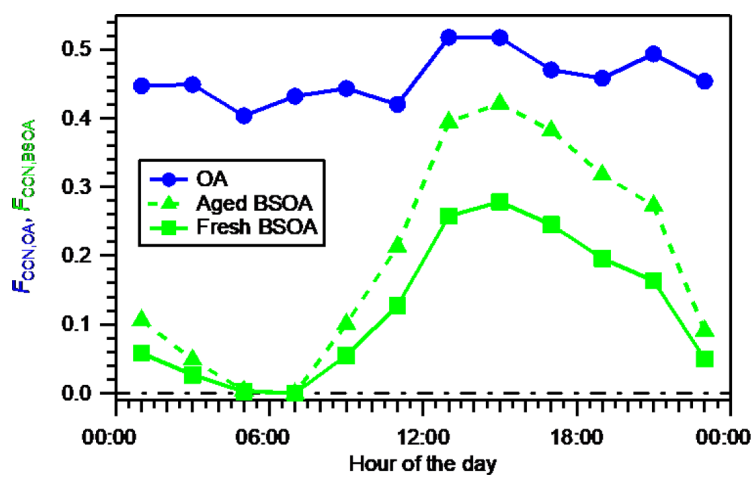

Figure 6. Diurnal variation in the fractional contribution of OA to the total $\mathrm{CCN}$ number concentration $\left(F_{\mathrm{CCN}, \mathrm{OA}}\right)$ estimated using time- and size-resolved $\kappa_{\text {org }}$, and diurnal variation in the fractional contribution of BSOA to the total $\mathrm{CCN}$ number concentration $\left(F_{\mathrm{CCN}, \mathrm{BSOA}}\right)$ estimated assuming fresh BSOA (using size-resolved $\left.\kappa_{\mathrm{BSOA}}\right)$ and aged BSOA (using size-resolved $\kappa_{\mathrm{ROA}}$ ).

case (0a), as presented in Fig. 7a. Using time-averaged $\kappa_{\text {org }}$ (case $1 \mathrm{a}$ ), the $F_{\mathrm{CCN} \text { OA }}$ was overestimated by $18 \%$ during 16:00-18:00 JST and underestimated by $13 \%$ during 06:00-08:00 JST. Using size-averaged $\kappa_{\text {org }}$ (case 2a), the $F_{\mathrm{CCN}, \mathrm{OA}}$ was overestimated by $2 \%-19 \%$ on a diurnal basis. Using time- and size-averaged $\kappa_{\text {org }}$ (i.e., a single mean $\kappa_{\text {org }}$, case $3 \mathrm{a}$ ), $F_{\mathrm{CCN}, \mathrm{OA}}$ was overestimated by $26 \%$ during 16:00-18:00 JST and underestimated by $5.0 \%$ during $06: 00-$ 08:00 JST. The deviation of case (3a) from the base case (0a) resulted from the factors leading to the deviations of cases (1a) and (2a). The magnitudes of the deviations, defined here as the difference between the lowest and highest values of the ratios in Fig. 7a, for (1a), (2a), and (3a) are $31 \%, 17 \%$, and $31 \%$, respectively. The substantial differences suggest that the diurnal variations and size dependence of $\kappa_{\text {org }}$ are important for accurate prediction of the contribution of $\mathrm{OA}$ to the $\mathrm{CCN}$ number concentration in modeling studies. To assess the influence of the size dependence of $\kappa_{\mathrm{BSOA}}$ on $F_{\mathrm{CCN} \text {,BSOA }}$, the diurnal variations in $F_{\mathrm{CCN} \text {,BSOA }}$ was estimated using $\left(0 \mathrm{~b}\right.$, base case) size-resolved $\kappa_{\mathrm{BSOA}}$ and $(1 \mathrm{~b})$ size-averaged $\kappa_{\mathrm{BSOA}}$ (Table S11). Case (1b) was compared with case $(0 \mathrm{~b})$, as presented in Fig. 7b. Using size-averaged $\kappa_{\mathrm{BSOA}}$ caused overestimation of $F_{\mathrm{CCN}, \mathrm{BSOA}}$ by $12 \%-19 \%$, which relates to the decrease in the estimated $\kappa_{\mathrm{BSOA}}$ and the increase in $\mathrm{d} N_{\mathrm{CN}} / \mathrm{d} \log d_{\text {dry }}$ (Fig. S17) with decrease in the dry particle diameter.

Furthermore, because fresh BSOA probably become aged after atmospheric transport, the influence of the aging of the estimated fresh BSOA (assuming $\kappa_{\mathrm{BSOA}}$ for the calculation of $d_{\text {act }}$ and $F_{\mathrm{CCN}, \mathrm{BSOA}}$ was as large as that of $\kappa_{\mathrm{ROA}}$, Table $\mathrm{S} 11)$ on $F_{\mathrm{CCN}, \mathrm{BSOA}}$ was also evaluated. Here, the estimation of $F_{\mathrm{CCN}, \mathrm{BSOA}}$ in the aged condition ignored the possible change in the aerosol size distribution accompanying the aging process. Aged BSOA can contribute more to the aerosol water uptake and thus to the $\mathrm{CCN}$ number concentra- 

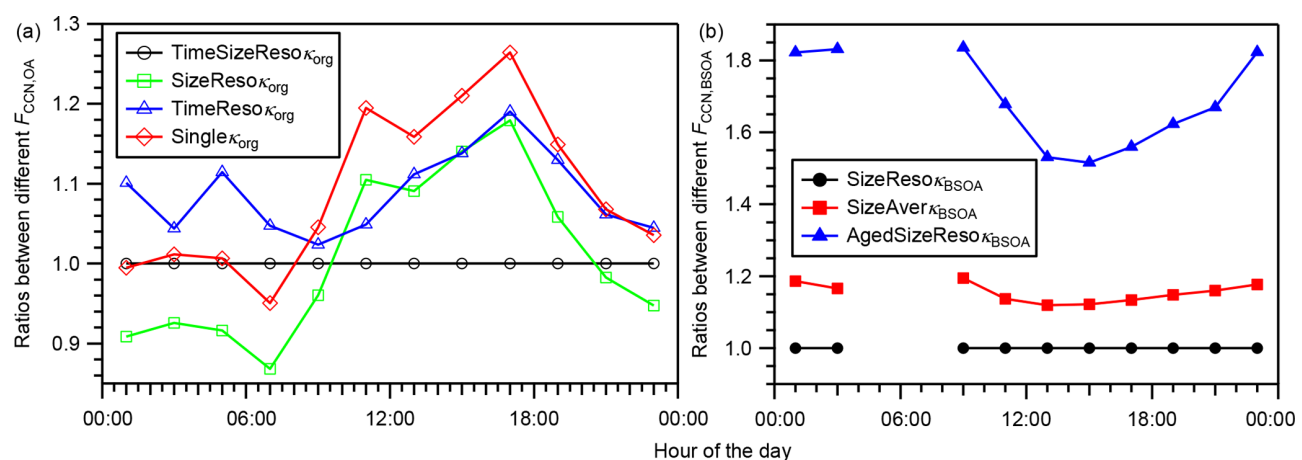

Figure 7. (a) Diurnal variation in the ratios of the $F_{\mathrm{CCN}, \mathrm{OA}}$ derived using time- and size-resolved $\kappa_{\mathrm{org}}$ (TimeSizeReso $\kappa_{\mathrm{org}}$ ), time-averaged and size-resolved $\kappa_{\mathrm{org}}\left(\right.$ SizeReso $\kappa_{\mathrm{org}}$ ), size-averaged and time-resolved $\kappa_{\mathrm{org}}$ (TimeReso $\kappa_{\mathrm{org}}$ ), and time- and size-averaged $\kappa_{\mathrm{org}}\left(\mathrm{Single} \kappa_{\mathrm{org}}\right)$ to that derived using the time- and size- resolved $\kappa_{\mathrm{org}}$ (TimeSizeReso $\kappa_{\mathrm{org}}$ ). (b) Diurnal variation in the ratios of the $F_{\mathrm{CCN} \text {, BSOA }}$ derived using size-resolved $\kappa_{\mathrm{BSOA}}\left(\right.$ SizeReso $\left.\kappa_{\mathrm{BSOA}}\right)$, size-averaged $\kappa_{\mathrm{BSOA}}\left(\right.$ SizeAver $\kappa_{\mathrm{BSOA}}$ ), and aged size-resolved $\kappa_{\mathrm{BSOA}}\left(\mathrm{AgedSizeReso} \kappa_{\mathrm{BSOA}}\right)$ to that derived using the size-resolved $\kappa_{\mathrm{BSOA}}$ (SizeReso $\kappa_{\mathrm{BSOA}}$ ). In panel (b), the condition of aged size-resolved $\kappa_{\mathrm{BSOA}}$ assumes that the value of $\kappa_{\mathrm{BSOA}}$ equals that of $\kappa_{\mathrm{ROA}}$, and the data during 04:00-08:00 JST, when the concentration of BSOA was low (volume concentration less than $0.01 \times 10^{-6} \mathrm{~cm}^{3} \mathrm{~m}^{-3}$ ), are not presented (data are presented in Table S12).

tion. Assuming that the BSOA was as aged as ROA, the estimated $F_{\mathrm{CCN}, \mathrm{BSOA}}$ was $52 \%-84 \%$ larger than that estimated assuming fresh BSOA (Fig. 7b), and it could have been 0.42 if the aerosol observed during 14:00-16:00 JST aged (Fig. 6). The result suggests that, whereas the contribution of BSOA to $\mathrm{CCN}$ was substantial at the study site, the magnitude of the contribution might be increased substantially by aging of the BSOA during transport after its formation in the forest.

\section{Summary and conclusions}

The size-resolved hygroscopicity at $85 \% \mathrm{RH}$, chemical composition, and number-size distributions of atmospheric aerosols were observed at a forest site in Wakayama, Japan, in August and September 2015. The diurnal variation and size dependence in the hygroscopicity of the observed aerosol and organic aerosol (OA) components were discussed in view of the formation of BSOA. The fractional contributions of OA and BSOA to the total $\mathrm{CCN}$ number concentration were discussed in view of the variations in the hygroscopicity parameter of OA and BSOA.

Similar to two previous observations at the same site (Han et al., 2013, 2014; Kawana et al., 2017; Deng et al., 2018), OA was the dominant sub-micrometer aerosol component, followed by sulfate. While the mass concentration of sulfate, on average, did not vary much in a day, the mass concentration of OA increased substantially in the afternoon hours, which was presumably explained by the condensation of BSOA. The hygroscopicity of ambient aerosol $\left(\kappa_{t}\right)$ and of OA $\left(\kappa_{\text {org }}\right)$ increased with an increase in the dry particle diameter and presented daily minima in the afternoon hours. In this study, the ranges of the diurnal variations in $\kappa_{\text {org }}$ of 100 $360 \mathrm{~nm}$ particles were $0.079-0.11$ and the $\kappa_{\text {org }}$ of $300 \mathrm{~nm}$ particles was 0.056 larger than that of the $100 \mathrm{~nm}$ particles. The diurnal variations and size dependence of $\kappa_{t}$ can be explained by the relative contributions of OA and inorganic salts in the observed aerosol. The relative contributions of the estimated fresh BSOA and regional OA can explain $40 \%$ of the diurnal variation and size dependence of $\kappa_{\text {org }}$. The hygroscopicity of fresh BSOA $\left(\kappa_{\mathrm{BSOA}}\right)$ was estimated to increase $(0.089-0.12)$ with an increase in the dry particle diameter $(100-300 \mathrm{~nm})$.

The fractional contributions of OA and fresh BSOA to $\mathrm{CCN}$ number concentrations, estimated from the viewpoint of their contributions to the water uptake by the aerosol, were in the ranges $0.40-0.52$ and $0.00-0.28$, respectively. Compared with the use of time- and size-resolved $\kappa_{\text {org }}$, the use of time- and size-averaged $\kappa_{\text {org }}$ overestimated the contribution of $\mathrm{OA}$ to the $\mathrm{CCN}$ number concentration by up to $26 \%$ (16:00-18:00 JST) and underestimated the contribution by up to $5.0 \%$ (06:00-08:00 JST). These results indicate the importance of the diurnal variations and size dependence of $\kappa_{\text {org }}$ in the prediction of the contribution of OA to the $\mathrm{CCN}$ number concentration. The use of size-averaged $\kappa_{\mathrm{BSOA}}$ overestimated the contribution of fresh BSOA to the CCN number concentration by $12 \%-19 \%$ compared with the use of size-resolved $\kappa_{\mathrm{BSOA}}$. If aging of BSOA after atmospheric transport occurs, the contribution of fresh BSOA to the CCN number concentration could be increased by $52 \%-84 \%$, and could have reached a high value of 0.42 if the aerosol observed during 14:00-16:00 JST aged.

This study revealed the large magnitude of the diurnal variation and size dependence of $\kappa_{\text {org }}$ at the observation site under the influence of the formation of BSOA. Also revealed was the importance of the variation in $\kappa_{\text {org }}$ to the estimation of the contribution of $\mathrm{OA}$ to the $\mathrm{CCN}$ number concentration from the viewpoint of the size-resolved contribution of OA to the water uptake of aerosols. Because both the diurnal variation and size dependence of $\kappa_{\text {org }}$ in the studied forest are dif- 
ferent from those in some other forest environments (Cerully et al., 2015; Thalman et al., 2017), further studies on the variation in the hygroscopicity of organics and on the contributions of $\mathrm{OA}$ and BSOA to the $\mathrm{CCN}$ concentrations should be performed in other forest environments. Furthermore, the size dependence of the hygroscopicity of fresh BSOA estimated here should be confirmed by additional studies.

Data availability. Raw data used to derive the data presented are available on request to the corresponding author. All of the final derived data supporting the findings of this study are available in the article or in the Supplement.

Supplement. The supplement related to this article is available online at: https://doi.org/10.5194/acp-19-5889-2019-supplement.

Author contributions. MM and YD designed the experiments, and YD, HY, MM, HF, and TN performed them. YD analyzed the data with contributions from MM, TN, and KK. YD prepared the manuscript with contributions from MM, KK, and TN.

Competing interests. The authors declare that they have no conflict of interest.

Acknowledgements. We thank the faculty and staff of the Wakayama Forest Research Station, Field Science Education and Research Center of Kyoto University, Japan, for the provision of the study site and the meteorological data. We thank Qingcai Chen, Kouji Adachi, Yuuki Kuruma, Ryuji Fujimori, and Takayuki Yamasaki for their help in the field observation. We acknowledge Kazuma Aoki for the use of the 1 $\lambda$-PSAP instrument. We acknowledge the NOAA Air Resources Laboratory (ARL) for providing the HYSPLIT transport and dispersion model. This study was supported in part by JSPS KAKENHI grant numbers JP26281007 and JP18K19852.

Review statement. This paper was edited by Veli-Matti Kerminen and reviewed by three anonymous referees.

\section{References}

Bougiatioti, A., Bezantakos, S., Stavroulas, I., Kalivitis, N., Kokkalis, P., Biskos, G., Mihalopoulos, N., Papayannis, A., and Nenes, A.: Biomass-burning impact on CCN number, hygroscopicity and cloud formation during summertime in the eastern Mediterranean, Atmos. Chem. Phys., 16, 7389-7409, https://doi.org/10.5194/acp-16-7389-2016, 2016.

Cerully, K. M., Bougiatioti, A., Hite Jr., J. R., Guo, H., Xu, L., $\mathrm{Ng}$, N. L., Weber, R., and Nenes, A.: On the link between hygroscopicity, volatility, and oxidation state of ambient and water-soluble aerosols in the southeastern United States, Atmos. Chem. Phys., 15, 8679-8694, https://doi.org/10.5194/acp15-8679-2015, 2015.

Clegg, S. L., Brimblecombe, P., and Wexler, A. S.: Thermodynamic model of the system $\mathrm{H}^{+}-\mathrm{NH}_{4}^{+}-\mathrm{SO}_{4}^{-2}-\mathrm{NO}_{3}^{-}-\mathrm{H}_{2} \mathrm{O}$ at tropospheric temperatures, J. Phys. Chem. A, 102, 2137-2154, https://doi.org/10.1021/jp973042r, 1998.

Deng, Y. G., Kagami, S., Ogawa, S., Kawana, K., Nakayama, T., Kubodera, R., Adachi, K., Hussein, T., Miyazaki, Y., and Mochida, M.: Hygroscopicity of Organic Aerosols and Their Contributions to CCN Concentrations Over a Midlatitude Forest in Japan, J. Geophys. Res.-Atmos., 123, 9703-9723, https://doi.org/10.1029/2017jd027292, 2018.

Draxler, R. R. and Hess, G. D.: An overview of the HYSPLIT_4 modelling system for trajectories, dispersion and deposition, Aust. Meteorol. Mag., 47, 295-308, 1998.

Ehn, M., Thornton, J. A., Kleist, E., Sipila, M., Junninen, H., Pullinen, I., Springer, M., Rubach, F., Tillmann, R., Lee, B., Lopez-Hilfiker, F., Andres, S., Acir, I. H., Rissanen, M., Jokinen, T., Schobesberger, S., Kangasluoma, J., Kontkanen, J., Nieminen, T., Kurten, T., Nielsen, L. B., Jorgensen, S., Kjaergaard, H. G., Canagaratna, M., Dal Maso, M., Berndt, T., Petaja, T., Wahner, A., Kerminen, V. M., Kulmala, M., Worsnop, D. R., Wildt, J., and Mentel, T. F.: A large source of lowvolatility secondary organic aerosol, Nature, 506, 476-479, https://doi.org/10.1038/nature13032, 2014.

Farmer, D. K., Cappa, C. D., and Kreidenweis, S. M.: Atmospheric processes and their controlling influence on cloud condensation nuclei activity, Chem. Rev., 115, 4199-4217, https://doi.org/10.1021/cr5006292, 2015.

Frosch, M., Bilde, M., DeCarlo, P. F., Juranyi, Z., Tritscher, T., Dommen, J., Donahue, N. M., Gysel, M., Weingartner, E., and Baltensperger, U.: Relating cloud condensation nuclei activity and oxidation level of alpha-pinene secondary organic aerosols, J. Geophys. Res.-Atmos., 116, D22212, https://doi.org/10.1029/2011jd016401, 2011.

Frosch, M., Bilde, M., Nenes, A., Praplan, A. P., Jurányi, Z., Dommen, J., Gysel, M., Weingartner, E., and Baltensperger, U.: $\mathrm{CCN}$ activity and volatility of $\beta$-caryophyllene secondary organic aerosol, Atmos. Chem. Phys., 13, 2283-2297, https://doi.org/10.5194/acp-13-2283-2013, 2013.

Han, Y. M., Iwamoto, Y., Nakayama, T., Kawamura, K., Hussein, T., and Mochida, M.: Observation of new particle formation over a mid-latitude forest facing the North Pacific, Atmos. Environ., 64, 77-84, https://doi.org/10.1016/j.atmosenv.2012.09.036, 2013.

Han, Y. M., Iwamoto, Y., Nakayama, T., Kawamura, K., and Mochida, M.: Formation and evolution of biogenic secondary organic aerosol over a forest site in Japan, J. Geophys. Res.Atmos., 119, 259-273, https://doi.org/10.1002/2013jd020390, 2014.

Jimenez, J. L., Canagaratna, M. R., Donahue, N. M., Prevot, A. S. H., Zhang, Q., Kroll, J. H., DeCarlo, P. F., Allan, J. D., Coe, H., Ng, N. L., Aiken, A. C., Docherty, K. S., Ulbrich, I. M., Grieshop, A. P., Robinson, A. L., Duplissy, J., Smith, J. D., Wilson, K. R., Lanz, V. A., Hueglin, C., Sun, Y. L., Tian, J., Laaksonen, A., Raatikainen, T., Rautiainen, J., Vaattovaara, P., Ehn, M., Kulmala, M., Tomlinson, J. M., Collins, D. R., Cubison, M. J., Dunlea, E. J., Huffman, J. A., Onasch, T. B., Alfarra, M. R., Williams, P. I., Bower, K., Kondo, Y., Schneider, J., Drewnick, 
F., Borrmann, S., Weimer, S., Demerjian, K., Salcedo, D., Cottrell, L., Griffin, R., Takami, A., Miyoshi, T., Hatakeyama, S., Shimono, A., Sun, J. Y., Zhang, Y. M., Dzepina, K., Kimmel, J. R., Sueper, D., Jayne, J. T., Herndon, S. C., Trimborn, A. M., Williams, L. R., Wood, E. C., Middlebrook, A. M., Kolb, C. E., Baltensperger, U., and Worsnop, D. R.: Evolution of Organic Aerosols in the Atmosphere, Science, 326, 1525-1529, https://doi.org/10.1126/science.1180353, 2009.

Kawana, K., Nakayama, T., and Mochida, M.: Hygroscopicity and $\mathrm{CCN}$ activity of atmospheric aerosol particles and their relation to organics: Characteristics of urban aerosols in Nagoya, Japan, J. Geophys. Res.-Atmos., 121, 4100-4121, https://doi.org/10.1002/2015jd023213, 2016.

Kawana, K., Nakayama, T., Kuba, N., and Mochida, M.: Hygroscopicity and cloud condensation nucleus activity of forest aerosol particles during summer in Wakayama, Japan, J. Geophys. Res.-Atmos., 122, 3042-3064, https://doi.org/10.1002/2016jd025660, 2017

Kondo, Y., Sahu, L., Kuwata, M., Miyazaki, Y., Takegawa, N., Moteki, N., Imaru, J., Han, S., Nakayama, T., Oanh, N. T. K., Hu, M., Kim, Y. J., and Kita, K.: Stabilization of the Mass Absorption Cross Section of Black Carbon for Filter-Based Absorption Photometry by the use of a Heated Inlet, Aerosol Sci. Tech., 43, 741-756, https://doi.org/10.1080/02786820902889879, 2009.

Kyoto University: Kenkyurin Shikenchi Joho 2010, in: Sections of Forest Station Management and Field Station Management, Field Science Education and Research Center, Kyoto University, Japan, 2017 (in Japanese).

Levin, E. J. T., Prenni, A. J., Palm, B. B., Day, D. A., Campuzano-Jost, P., Winkler, P. M., Kreidenweis, S. M., DeMott, P. J., Jimenez, J. L., and Smith, J. N.: Size-resolved aerosol composition and its link to hygroscopicity at a forested site in Colorado, Atmos. Chem. Phys., 14, 2657-2667, https://doi.org/10.5194/acp-14-2657-2014, 2014.

Liu, X. H. and Wang, J. A.: How important is organic aerosol hygroscopicity to aerosol indirect forcing?, Environ. Res. Lett., 5, 044010, https://doi.org/10.1088/1748-9326/5/4/044010, 2010.

McFiggans, G., Artaxo, P., Baltensperger, U., Coe, H., Facchini, M. C., Feingold, G., Fuzzi, S., Gysel, M., Laaksonen, A., Lohmann, U., Mentel, T. F., Murphy, D. M., O’Dowd, C. D., Snider, J. R., and Weingartner, E.: The effect of physical and chemical aerosol properties on warm cloud droplet activation, Atmos. Chem. Phys., 6, 2593-2649, https://doi.org/10.5194/acp-6-25932006, 2006.

McNeill, V. F.: Aqueous Organic Chemistry in the Atmosphere: Sources and Chemical Processing of Organic Aerosols, Environ. Sci. Technol., 49, 1237-1244, https://doi.org/10.1021/es5043707, 2015.

Mei, F., Hayes, P. L., Ortega, A., Taylor, J. W., Allan, J. D., Gilman, J., Kuster, W., de Gouw, J., Jimenez, J. L., and Wang, J.: Droplet activation properties of organic aerosols observed at an urban site during CalNex-LA, J. Geophys. Res.-Atmos., 118, 2903-2917, https://doi.org/10.1002/jgrd.50285, 2013a.

Mei, F., Setyan, A., Zhang, Q., and Wang, J.: CCN activity of organic aerosols observed downwind of urban emissions during CARES, Atmos. Chem. Phys., 13, 12155-12169, https://doi.org/10.5194/acp-13-12155-2013, 2013b.

Mochida, M., Nishita-Hara, C., Kitamori, Y., Aggarwal, S. G., Kawamura, K., Miura, K., and Takami, A.: Size- segregated measurements of cloud condensation nucleus activity and hygroscopic growth for aerosols at Cape Hedo, Japan, in spring 2008, J. Geophys. Res.-Atmos., 115, D21207, https://doi.org/10.1029/2009jd013216, 2010.

Okumura, M.: Estimation of volatile organic compound emissions from forest vegetation, PhD thesis, Graduate School of Energy Science, Kyoto University, Kyoto, Japan, 2009.

Paatero, P. and Tapper, U.: Positive matrix factorization a nonnegative factor model with optimal utilization of error-estimates of data values, Environmetrics, 5, 111-126, https://doi.org/10.1002/env.3170050203, 1994.

Petters, M. D. and Kreidenweis, S. M.: A single parameter representation of hygroscopic growth and cloud condensation nucleus activity, Atmos. Chem. Phys., 7, 1961-1971, https://doi.org/10.5194/acp-7-1961-2007, 2007.

Pöschl, U., Martin, S. T., Sinha, B., Chen, Q., Gunthe, S. S., Huffman, J. A., Borrmann, S., Farmer, D. K., Garland, R. M., Helas, G., Jimenez, J. L., King, S. M., Manzi, A., Mikhailov, E., Pauliquevis, T., Petters, M. D., Prenni, A. J., Roldin, P., Rose, D., Schneider, J., Su, H., Zorn, S. R., Artaxo, P., and Andreae, M. O.: Rainforest Aerosols as Biogenic Nuclei of Clouds and Precipitation in the Amazon, Science, 329, 15131516, https://doi.org/10.1126/science.1191056, 2010.

Rastak, N., Pajunoja, A., Navarro, J. C. A., Ma, J., Song, M., Partridge, D. G., Kirkevag, A., Leong, Y., Hu, W. W., Taylor, N. F., Lambe, A., Cerully, K., Bougiatioti, A., Liu, P., Krejci, R., Petaja, T., Percival, C., Davidovits, P., Worsnop, D. R., Ekman, A. M. L., Nenes, A., Martin, S., Jimenez, J. L., Collins, D. R., Topping, D. O., Bertram, A. K., Zuend, A., Virtanen, A., and Riipinen, I.: Microphysical explanation of the RH-dependent water affinity of biogenic organic aerosol and its importance for climate, Geophys. Res. Lett., 44, 5167-5177, https://doi.org/10.1002/2017gl073056, 2017.

Shingler, T., Crosbie, E., Ortega, A., Shiraiwa, M., Zuend, A., Beyersdorf, A., Ziemba, L., Anderson, B., Thornhill, L., Perring, A. E., Schwarz, J. P., Campazano-Jost, P., Day, D. A., Jimenez, J. L., Hair, J. W., Mikoviny, T., Wisthaler, A., and Sorooshian, A.: Airborne characterization of subsaturated aerosol hygroscopicity and dry refractive index from the surface to $6.5 \mathrm{~km}$ during the SEAC(4)RS campaign, J. Geophys. Res.-Atmos., 121, 41884210, https://doi.org/10.1002/2015jd024498, 2016.

Thalman, R., de Sá, S. S., Palm, B. B., Barbosa, H. M. J., Pöhlker, M. L., Alexander, M. L., Brito, J., Carbone, S., Castillo, P., Day, D. A., Kuang, C., Manzi, A., Ng, N. L., Sedlacek III, A. J., Souza, R., Springston, S., Watson, T., Pöhlker, C., Pöschl, U., Andreae, M. O., Artaxo, P., Jimenez, J. L., Martin, S. T., and Wang, J.: CCN activity and organic hygroscopicity of aerosols downwind of an urban region in central Amazonia: seasonal and diel variations and impact of anthropogenic emissions, Atmos. Chem. Phys., 17, 11779-11801, https://doi.org/10.5194/acp-1711779-2017, 2017.

Titos, G., Cazorla, A., Zieger, P., Andrews, E., Lyamani, H., Granados-Munoz, M. J., Olmo, F. J., and AladosArboledas, L.: Effect of hygroscopic growth on the aerosol light-scattering coefficient: A review of measurements, techniques and error sources, Atmos. Environ., 141, 494-507, https://doi.org/10.1016/j.atmosenv.2016.07.021, 2016.

Tritscher, T., Dommen, J., DeCarlo, P. F., Gysel, M., Barmet, P. B., Praplan, A. P., Weingartner, E., Prévôt, A. S. H., Ri- 
ipinen, I., Donahue, N. M., and Baltensperger, U.: Volatility and hygroscopicity of aging secondary organic aerosol in a smog chamber, Atmos. Chem. Phys., 11, 11477-11496, https://doi.org/10.5194/acp-11-11477-2011, 2011.

Tunved, P., Hansson, H. C., Kerminen, V. M., Strom, J., Dal Maso, M., Lihavainen, H., Viisanen, Y., Aalto, P. P., Komppula, M., and Kulmala, M.: High natural aerosol loading over boreal forests, Science, 312, 261-263, https://doi.org/10.1126/science.1123052, 2006.

Ulbrich, I. M., Canagaratna, M. R., Zhang, Q., Worsnop, D. R., and Jimenez, J. L.: Interpretation of organic components from Positive Matrix Factorization of aerosol mass spectrometric data, Atmos. Chem. Phys., 9, 2891-2918, https://doi.org/10.5194/acp-92891-2009, 2009.

Vaishya, A., Ovadnevaite, J., Bialek, J., Jennings, S. G., Ceburnis, D., and O'Dowd, C. D.: Bistable effect of organic enrichment on sea spray radiative properties, Geophys. Res. Lett., 40, 63956398, https://doi.org/10.1002/2013g1058452, 2013.

Vargaftik, N. B., Volkov, B. N., and Voljak, L. D.: International tables of the surface-tension of water, J. Phys. Chem. Ref. Data, 12, 817-820, https://doi.org/10.1063/1.555688, 1983.

Wang, J., Lee, Y.-N., Daum, P. H., Jayne, J., and Alexander, M. L.: Effects of aerosol organics on cloud condensation nucleus $(\mathrm{CCN})$ concentration and first indirect aerosol effect, Atmos. Chem. Phys., 8, 6325-6339, https://doi.org/10.5194/acp-8-63252008, 2008.

Wexler, A. S. and Clegg, S. L.: Atmospheric aerosol models for systems including the ions $\mathrm{H}^{+}, \mathrm{NH}_{4}^{+}, \mathrm{Na}^{+}, \mathrm{SO}_{4}^{2-}, \mathrm{NO}_{3}^{-}$, $\mathrm{Cl}^{-}, \mathrm{Br}^{-}$, and $\mathrm{H}_{2} \mathrm{O}$, J. Geophys. Res.-Atmos., 107, D14, https://doi.org/10.1029/2001jd000451, 2002.

Winkler, P. M., Ortega, J., Karl, T., Cappellin, L., Friedli, H. R., Barsanti, K., McMurry, P. H., and Smith, J. N.: Identification of the biogenic compounds responsible for sizedependent nanoparticle growth, Geophys. Res. Lett., 39, L20815, https://doi.org/10.1029/2012g1053253, 2012.
Yu, H., Ortega, J., Smith, J. N., Guenther, A. B., Kanawade, V. P., You, Y., Liu, Y. Y., Hosman, K., Karl, T., Seco, R., Geron, C., Pallardy, S. G., Gu, L. H., Mikkila, J., and Lee, S. H.: New Particle Formation and Growth in an Isoprene-Dominated Ozark Forest: From Sub-5 nm to CCN-Active Sizes, Aerosol Sci. Tech., 48, 1285-1298, https://doi.org/10.1080/02786826.2014.984801, 2014.

Zhang, Q., Jimenez, J. L., Canagaratna, M. R., Ulbrich, I. M., Ng, N. L., Worsnop, D. R., and Sun, Y. L.: Understanding atmospheric organic aerosols via factor analysis of aerosol mass spectrometry: a review, Anal. Bioanal. Chem., 401, 3045-3067, https://doi.org/10.1007/s00216-011-5355-y, 2011.

Zhao, D. F., Buchholz, A., Kortner, B., Schlag, P., Rubach, F., Kiendler-Scharr, A., Tillmann, R., Wahner, A., Flores, J. M., Rudich, Y., Watne, A. K., Hallquist, M., Wildt, J., and Mentel, T. F.: Size-dependent hygroscopicity parameter $(\kappa)$ and chemical composition of secondary organic cloud condensation nuclei, Geophys. Res. Lett., 42, 10920-10928, https://doi.org/10.1002/2015gl066497, 2015.

Zhao, Y., Wingen, L. M., Perraud, V., and Finlayson-Pitts, B. J.: Phase, composition, and growth mechanism for secondary organic aerosol from the ozonolysis of a-cedrene, Atmos. Chem. Phys., 16, 3245-3264, https://doi.org/10.5194/acp-163245-2016, 2016.

Zhou, L., Gierens, R., Sogachev, A., Mogensen, D., Ortega, J., Smith, J. N., Harley, P. C., Prenni, A. J., Levin, E. J. T., Turnipseed, A., Rusanen, A., Smolander, S., Guenther, A. B., Kulmala, M., Karl, T., and Boy, M.: Contribution from biogenic organic compounds to particle growth during the 2010 BEACHON-ROCS campaign in a Colorado temperate needleleaf forest, Atmos. Chem. Phys., 15, 8643-8656, https://doi.org/10.5194/acp-15-8643-2015, 2015. 